\title{
COMMENTS
}

\section{PRUNING THE POLITICAI THICKET: THE CASE FOR STRICT SGRUTINY OF STATE BALLOT ACCESS RESTRICTIONS}

\author{
KEVIN COFSKY $†$
}

\section{INTRODUCTION}

In 1989, the world rejoiced as the fall of the Berlin Wall marked the end of an era of oppression for much of Eastern Europe. In the ensuing years, staggering changes have taken place in many areas of the world-the institution of market economics, free expression of speech, and open tolerance of religion. The most significant improvement-the prize for which the people of East Germany, Poland and the Soviet Union so valiantly strived-has been the proliferation of the right of self-determination, the freedom to shape one's own destiny, the ability to take part in the process of government. As the United States Supreme Court recognized in the seminal case of Wesberry $v$. Sanders, "[n]o right is more precious in a free country than that of having a voice in the election of those who make the laws under which, as good citizens, we must live. Other rights, even the most basic, are illusory if the right to vote is undermined."

In a representative democracy, the various political, economic and social rights guaranteed by the constitution or laws of the land are necessarily subject to the alteration or interpretation of a governing authority. ${ }^{2}$ Therefore, the manner in which the gov-

† B.S.E. 1992, Wharton School of Business; M.G.A. Candidate 1997, University of Pennsylvania; J.D. Candidate 1997, University of Pennsylvania. I would like to thank Chris Abbinante and Todd Rosenberg for their thoughtful suggestions, Chevanniese Smith for her endless patience and assiduousness, and Peter Blumberg for his fearless leadership of the Volume 145 Board of the Law Review. I would also like to thank my family and Ms. Renée Jarkovsky for their love and support.

"This is a wonderful thought to keep in mind all the way around the course.... Take dead aim, ... refuse to allow any negative thought to enter your head, and swing away." HARVEY PENICK ET AL., HARVEY PENICK's LITTLE RED BOOK: LESSONS AND TEACHINGS FORM A LIFETIME OF GOLF 45 (1992).

${ }^{1}$ Wesberry v. Sanders, 376 U.S. 1, 17 (1964).

2 But see Charles E. Lindblom, The Policy-Making Process 65-68 (2d ed. 1980) (asserting that implementation as well as creation of statutes affects policy because of 
erning authority ascertains and effectuates the will of the people ultimately determines the substance of the nation's legal framework and consequently, the nature of society. Accordingly, the most fundamental rights in such a system are those associated with the right to vote..$^{3}$ As James Madison stated in 1787 , " $[t]$ he genius of republican liberty [is] not only that all power should be derived from the people, but that those intrusted with it should be kept in dependence on the people."

Ironically, as many countries taking their first precious steps toward a freer society look to the United States as the prototypical modern democracy, American government seems to have stumbled. Decades of scandal have undermined the authority of government ${ }^{5}$ and a general feeling of discontent with Washington insiders has become commonplace. In response, many Americans have increasingly looked to "new faces" for political solutions. The independent candidacy of Ross Perot in 1992, the strong public support for General Colin Powell's candidacy in 1995, and the resiliency of Perot's

incomplete specification, conflicting directives, and the limited competence of bureaucrats to effectuate legislative objectives); THEODORE LOW, THE END OF LIBERALISM 106 (2d ed. 1979) (commenting that the elected government has abdicated much control to the bureaucracy as "modern law has become a series of instructions to administrators rather than a series of commands to citizens"). Additionally, nonelected partisan officials carry out many functions of the governing authority. Nevertheless, while elected officials do not maintain exclusive control over government functions, their ability to control the legislative agenda and their ultimate responsibility to the people ensure a minimum of popular control. See, e.g., LAURENCE H. TRIBE, AMERICAN CONSTITUtIONAL LAW 1451 (2d ed. 1988) (observing the "Madisonian ideal of law as the expression of a general public good").

${ }^{3}$ See AlEXANDER J. BOTT, HANDBOOK OF UNITED STATES ElECTION LAWS AND PRACTICES at xix (1990) (finding that "[t]he civil rights most basic to citizens of a democracy are the political rights to vote, gain ballot access, criticize the government in public, form political parties, and be kept informed of the government's activities"); Note, Developments in the Law-Elections, 88 HARV. L. REV. 1111, 1114 (1975) (stating that '[n]o institution is more central to the United States' system of representative democracy than the election"); James A. Gardner, Liberty, Community, and the Constitutional Structure of Political Influence: A Reconsideration of the Right to Vote, $145 \mathrm{U}$. PA. L. REV. (forthcoming Apr. 1997) (stating that "[t]o a degree unmatched in other areas, judicial and legislative actions affecting the right to vote may have immediate and decisive impacts on the nation's public life"); see also infra notes $47-49$ and accompanying text (describing in greater detail the constituent elements of the right to vote).

${ }^{4}$ The Federalist No. 37, at 227 (James Madison) (Clinton Rossiter ed., 1961).

${ }^{5}$ Many scholars recognize that episodes such as Watergate, the Iran-Contra affair, the savings and loan scandal, and Whitewater have a cumulatively disparaging impact on citizens' view of American government. Cf. RICHARD E. NEUSTADT, PRESIDENTIAL POWER 95-97 (1960) (suggesting that the public perception of the office of president changes over time). 
Reform Party are testaments to the pervasiveness and legitimacy of the dissatisfaction with the existing political choices that many Americans experience. ${ }^{6}$ Nevertheless, these challengers to the "existing order" have encountered substantial difficulty and expense in attempting to place their names on ballots. Thus, the courts recently have faced an increasing number of challenges to state election schemes and have addressed the validity of many ballot access restrictions.

Ballot access restrictions represent the organizational embodiment of the dyad between representation and governability. As a functional matter, a modicum of procedural regulation must exist in order to ensure the fair and efficient administration of elections. In addition, states have found it necessary to regulate the substance of elections for a number of reasons, such as preventing voter confusion, protecting the integrity of the two-party system, and maintaining the stability of the political process. Beyond these stated objectives however, majority parties have also found it politically expedient to utilize ballot access restrictions as a method of warding off unwanted competition.

In 1968, the Supreme Court began to address the constitutionality of state-imposed restrictions on access to the ballot for independent and third party candidates. In Williams $v$. Rhodes, the Court found unconstitutional an Ohio election code which "made it virtually impossible for a new political party ... to be placed on the state ballot." Unfortunately, in the ensuing three decades the Court's jurisprudence in this area has become riddled with inconsistencies and vague standards of review, leaving Lawrence Tribe to remark on "the doctrinal enigmas that bedevil the law of ballot access," and to conclude that the "Court's initial forays into the realm of access requirements were oblique and not wholly consistent." ${ }^{8}$ The Court's failure to act decisively and consistently in this

${ }^{6}$ For an example of the dissatisfaction with current political alternatives, see Future of American Politics (C-SPAN television broadcast, Jan. 8, 1995). David Kozak, a public policy professor at Gannon University, observed that poll data collected in 1995 while Ross Perot was hosting a political conference in Dallas, showed that greater than $60 \%$ of the American electorate wanted a third political party; greater than $50 \%$ wanted General Colin Powell or another independent candidate to run for the presidency in 1996; approximately $39 \%$ classified themselves as independents; and that the "floating vote" had recently increased from $20 \%$ to between $30 \%$ and $40 \%$. In sum, Mr. Kozak observed that it was "a time of great fluidity, volatility, shifting sands" in the political landscape. Id.

${ }^{7}$ Williams v. Rhodes, 393 U.S. 23, 24 (1968).

${ }^{8}$ TRIBE, supra note 2 , at 1102. 
area of the law has left lower courts without adequate guidance to determine future constitutional challenges and has resulted in a deterioration of states' confidence in the validity of their election schemes. In order to maintain a properly functioning electoral process, the Court must establish a clear standard of review for ballot access restrictions that is consistent with its other constitutional jurisprudence.

This Comment will argue that as long as the Court continues to analyze alleged violations of equal protection and substantive due process within the framework of tiered scrutiny, it must also consider the constitutional validity of ballot access restrictions within this framework. Further, because access restrictions necessarily implicate the freedom of political association and the right to vote-both of which the Court has affirmatively accepted as fundamental in character-such regulations must be examined through the lens of strict scrutiny. The Fourteenth Amendment provides that "[n]o State shall make or enforce any law which shall ... deprive any person of life, liberty, or property, without due process of law; nor deny to any person within its jurisdiction the equal protection of the laws." These prohibitions are commonly referred to, respectively, as the Due Process and Equal Protection Clauses respectively. Alleged violations are generally reviewed under a system of "tiered" scrutiny: a) rational basis-the Court will uphold state classifications that are not based on a "suspect" classification and do not impair a "fundamental right" so long as the classification bears a rational relationship to a legitimate government objective; ${ }^{10}$ b) mid-level scrutiny-the Court has required that "classifications by gender must serve important governmental objectives and must be substantially related to achievement of those objectives"; will only uphold state regulations that impinge on "fundamental" rights or classifications that are based on "suspect" classifications if such restrictions are "narrowly tailored to serve a compelling state interest."12 As the Court created strict scrutiny to protect funda-

${ }^{9}$ U.S. CONST. amend. XIV, $\S 1$.

${ }^{10}$ See City of New Orleans v. Dukes, 427 U.S. 297, 303 (1976) ("Unless a classification trammels fundamental personal rights or is drawn upon inherently suspect distinctions such as race, religion, or alienage, our decisions presume the constitutionality of the statutory discriminations and require only that the classification challenged be rationally related to a legitimate state interest.").

${ }^{11}$ Craig v. Boren, 429 U.S. 190, 197 (1976).

12 See, e.g., Korematsu v. United States, 323 U.S. 214 (1944) (applying strict scrutiny and referring to race as a "suspect" class); McLaughlin v. Florida, 379 U.S. 184 (1964) 
mental rights, it is logically inconsistent and intuitively unreasonable for the Court to deny this heightened scrutiny to two of our "most precious freedoms."13 The Court must therefore employ a strict scrutiny analysis that both recognizes the fundamental nature of the individual rights infringed and enables states to effectively regulate the electoral process.

Part I of this Comment will briefly illustrate the evolution of and statutory response to the electoral system in the United States in order to place the later discussion concerning modern ballot access restrictions in the appropriate context. Part II will present the basic constitutional parameters that empower the states to regulate ballot access and through which the Court must view the validity of such regulations.

Part III will trace the jurisprudential history of ballot access restrictions, conclusively demonstrating the capriciousness of the Court's decisions. As this Section will show, the Court has failed to articulate a consistent analytical standard with which to evaluate state ballot access restrictions, appearing instead to rely on distinct standards in each case. ${ }^{14}$ The result of the Court's lack of logical consistency has been a dearth of reliable precedent to guide lower courts in their evaluation of election law, and an inability on the part of states to proactively construct election schemes with any degree of confidence in the constitutional viability of their efforts.

(using strict scrutiny to stike a race-based law). But cf. Eugene Volokh, Freedom of Speech, Permissible Tailoring and Transcending Strict Scrutiny, 144 U. PA. L. REV. 2417, 2417 (1996) (asserting that strict scrutiny is an inadequate mechanism by which to protect content-based restrictions on fully protected speech). See generally TRIBE, supra note 2, at 1451-54; Barry Friedman, Dialogue and Judicial Review, 91 MICH. L. REV. 577, 591 (1993) ("Courts often make decisions about whether to trump government action with a thumb on the side of the scale that represents the will of the ostensibly majoritarian branches. This is true . . o of any form of tiered review, such as that used for equal protection and substantive due process claims."). For a satirical overview of the Court's use of tiered scrutiny, see United States v. Virginia, 116 S. Ct. 2264, 2292 (1996) (Scalia, J., dissenting) (referring to the Court's "current equal-protection jurisprudence, which regards this Court as free to evaluate everything under the sun by applying one of three tests: 'rational basis' scrutiny, intermediate scrutiny, or strict scrutiny").

13 Williams, 393 U.S. at 30.

${ }_{14}$ See Brian L. Porto, The Constitution and the Ballot Box: Supreme Court Jurisprudence and Ballot Access for Independent Candidates, 7 BYU J. PUB. L. 281, 282 (1993) (discussing the widely-held view that the Court relied "on a different standard from one ballot access case to the next ${ }^{n}$ ); Bradley A. Smith, Note, Judicial Protection of BallotAccess Rights: Third Parties Need Not Apply, 28 HARV. J. ON LEGIS. 167, 186-87 (1991) (noting that the Supreme Court has applied rigorous strict scrutiny as well as minimal scrutiny). 
Part IV will examine recent circuit and district court opinions as conclusive evidence of the utter confusion in the lower courts regarding the proper method of analysis for constitutional challenges to ballot access restrictions.

Part V proposes an approach to analyzing constitutional challenges to state ballot access restrictions. This Part argues that assuming that the Court will continue to analyze alleged violations of equal protection and substantive due process within the framework of tiered scrutiny, the Court must examine all ballot access restrictions through the lens of strict scrutiny. Utilizing a genuine and nonconclusory tiered-scrutiny analysis that accords appropriate weight to both the states' objectives in regulating the ballot and the individual constitutional interests infringed will enable courts to strike state election schemes that unduly restrict the fundamental and precious freedoms of association and voting without " $t$ [ying] the hands" of state legislatures that wish to regulate the ballot. ${ }^{15}$

\section{History AND RATIONALE For BaLIOT ACCESS Restrictions}

As a purely functional matter, a fundamental level of regulation in the election of public officials must exist. Thus, in 1974 Justice White observed in Storer $v$. Brown that "as a practical matter, there must be a substantial regulation of elections if they are to be fair and honest and if some sort of order, rather than chaos, is to accompany the democratic processes." ${ }^{16}$ Nevertheless, although the establishment of a procedural context for the electoral process is undeniably essential to the orderly operation of a free society, in the modern era all states have developed far more extensive sets of regulations to govern the various aspects of the voting mechanism. A full understanding of the modern jurisprudential response to ballot access

${ }^{15}$ See Burdick v. Takushi, 504 U.S. 428, 433 (1992). Asserting that all election laws must necessarily "'affect[] . . . the individual's right to vote and his right to associate," Justice White concluded that "to subject every voting regulation to strict scrutiny and to require that the regulation be narrowly tailored to advance a compelling state interest . . . would tie the hands of States seeking to assure that elections are operated equitably and efficiently." Id. (quoting Anderson v. Celebrezze, 460 U.S. 780, 788 (1983)). Consequently, the Court in Burdick employed a "more flexible standard" than strict scrutiny. Id. at 434. But see infra Part V (arguing that the application of strict scrutiny should not necessarily be inconsistent with a finding that state election schemes are constitutionally valid).

${ }^{16}$ Storer v. Brown, 415 U.S. 724, 730 (1974); see also Note, supra note 3, at 1115 (observing that the establishment of a time and place for voting and the institution of a mechanism to record results are necessary functions of an electoral system). 
restrictions requires a proper familiarity with the historical development and rationale of such restrictions. In order to place the later discussion concerning modern ballot access restrictions in the appropriate context, this Part will briefly describe the evolution of and statutory response to the electoral system in the United States.

The first formal elections in the pre-revolutionary colonies were to the House of Burgesses in Virginia in 1619. As in many elections of the period, candidates ran on a self-selective basis and were unopposed. ${ }^{17}$ Because most elections continued to be uncontested throughout the pre-revolutionary period and into the nineteenth century, the colonies and states exercised little control over ballot access. ${ }^{18}$ As a result, in instances where the conclusion was not foregone, voters were typically influenced by intimidation and bribery. ${ }^{19}$ Interestingly, while many states regulated the physical specifications of ballots, they often required the candidates to print the ballots themselves, thereby excluding many from candidacy on the basis of wealth. ${ }^{20}$

The first major innovation in ballot access administration came in 1832, with the introduction of the "Australian ballot." The Australian ballot provided three significant modifications: 1) ballots were printed by state governments at taxpayers' expense; 2) ballots bore the names of all candidates who had been duly nominated according to state law; 3) ballots were distributed by the government at the site of the polls, marked in secret by each individual voter, and deposited in a ballot box. This development increased government involvement in the procedural administration of the electoral process and marked the genesis of government regulation and restriction of access to the ballot. ${ }^{21}$

Gradually, states developed complex schemes to determine precisely which individuals were to be placed on the ballot. ${ }^{22}$ States

${ }^{17}$ See BOTT, supra note 3, at 86 (recounting George Washington's candidacy for a seat in the Virginia House in 1755).

${ }^{18}$ See id. at 87 (observing that the colonies' limited role in controlling elections consisted primarily of setting the dates and places of elections and guarding against ballot stuffing and duplicate voting).

${ }^{19}$ See id. at 91 .

${ }^{20}$ See id. (describing how the cost of supplying ballots often discouraged independent candidates from running).

21 See id. (detailing the rise of the Australian ballot in America); see also EDWARD M. SAIT, AMERICAN PARTIES AND ELECTIONS 560-62 (1927) (noting that the Australian ballot was adopted in Massachusetts and Kentucky in 1888 and that 32 states had adopted the mechanism by 1892).

${ }^{22}$ For a thorough analysis of the development of ballot access restrictions, see 
have often defended these access restrictions as a means of promoting the legitimate interests of political stability, avoiding voter confusion, and minimizing polling expenses. ${ }^{23}$ However, the various political motivations behind state election schemes should not be overlooked. First, the two major parties may utilize such regulations to exclude minor parties and independent candidates from the political arena and thus eliminate challenges to their authority. ${ }^{24}$ Next, one of the major parties, having secured a majority position in the legislature, may manipulate the legal framework to consolidate this position by hindering the other major party during the election process. ${ }^{25}$ Finally, individuals in positions of power may attempt to reduce the challenge of dissident factions within their own party via restricted ballot access. ${ }^{26}$ As Part III will illustrate, while legal challenges have occurred with respect to all of these permutations, the greatest number of suits challenge ballot restrictions that result in the exclusion of third parties or independent candidates.

The regulation of political parties' access to the ballot is typically accomplished through a complex set of election guidelines. In

Porto, supra note 14, at 287-89. Modern ballot access restrictions are commonly viewed as having developed as a response to the success of the Progressive Party and the Socialist Party in the 1912 elections and fear of the Communist Party in the 1930s and 1940s. See id.

${ }^{23}$ See infra Part III.

${ }^{24}$ See BOTT, supra note 3, at 93 ("[B]y controlling the state governments, the two major parties have used the lawmaking process as one way to ward off any threat of significant challenges by third-party or independent candidates.").

${ }_{25}$ See, e.g., Reynolds v. Sims, 377 U.S. 533 (1964) (finding that malapportionment of Alabama state electoral districts denied citizens equal protection of the laws). In Reynolds, the apportionment of legislative districts had not been recalculated to account for the population shifts from rural to urban centers. Accordingly, rural districts were overrepresented in the state legislature. See id. at 544-46. As the Court noted that $25 \%$ of the state's population could control a majority of the legislature, it was reasonable to infer that the political groups representing these minority rural population centers opposed redistricting and its consequent loss of legislative power. See id. at 547.

${ }^{28}$ For a recent example of a state election scheme designed to ward off challenges within the party structure, see Rockefeller v. Powers, 909 F. Supp. 863 (E.D.N.Y. 1995), rev'd, Rockefeller v. Powers, 74 F.3d 1367 (2d Cir. 1995), discussed infra Part IV.F. Additionally, see Robert J. McCarthy, Forbes Hails Primary Ruling in Launching Upstate Drive, BuFF. NEwS, Dec. 1, 1995, at Al4 and No Contest: Until New York Republicans Rebel, the Party Bosses Will Dictate Their Choice for President, NEwSDAY, Nov. 30, 1995, at A40 (noting that Senator Alfonse D'Amato is seeking to "lock up the [Republican primary election in New York state] on behalf of Senator Bob Dole") for another instance of party incumbents seeking to manipulate election results via ballot access regulation. 
general, states have recognized three organizational means of political expression-majority or "established" political parties, "minor" or "new" political parties, and independent candidates. Most states grant automatic access to the ballot box for majority or existing parties. ${ }^{27}$ This status is reevaluated and legitimized on a regular basis, typically by securing a requisite percentage of the vote in a prior general election. ${ }^{28}$ A majority of the states also provide procedures that permit minor or new parties to qualify for the ballot, often by submitting petitions containing a minimum number of eligible voter signatures. ${ }^{29}$ Finally, independent candidates-those individuals not associated with any political party-may achieve access to the ballot by filing petitions demonstrating a minimum of popular support. $^{30}$

As a result of the categorical conception of political entities, state regulations concerning ballot access have come to be concentrated in two distinct areas. First, legislation determines the polling percentage necessary to receive the privileged status of "major" party, with its corresponding automatic access to the general election ballot. Second, statutes regulate the degree of popular support required and the manner in which this support must be demonstrated for minor parties or independent candidates to have their names placed on the ballot. Because the major parties substantively control the legislative process in most states, the statutory requirements typically do not present a problem for their continued access to the ballot. $^{31}$ Consequently, the areas of significant controversy have

27 See, e.g., ALA. CODE \$§17-7-1, 17-8-2.1, 17-16-5, 17-16-11, 17-16A-3, 17-19-2 (1995); ALASKA STAT. $\$ \S 15.25 .030,15.25 .160,15.25 .170,15.30 .020,15.30 .025,15.60 .010(12)$ (1988); CAL. ELEC. CODE $\$ \S 6340,6343,6520,6523,6121,6125,8400,6041,6061$, 6062 (West 1996). For illuminating overviews of state ballot access laws, see BOTT, supra note 3, at 114-38 tbl.3.2 and Note, supra note 3, at 112 n.1.

Other advantages given to majority parties include being given a column on the ballot box, having candidates listed as members of the party, or receiving public campaign financing. See BOTT, supra note 3, at 147 (discussing privileges afforded to large parties).

${ }^{28}$ For an elaboration on the great variation among states in the required percentage, see Note, supra note 3, at 1121 n.l.

${ }^{29}$ See id. at 1122; see also BOTT, supra note 3, at 146-47 (noting that while states have various labels for political entities that receive only a small quantum of voter support, virtually all states recognize this status as distinct from independent candidates or "major" parties).

${ }_{30}$ See BOTT, supra note 3, at 149-52 (describing state laws governing independent candidates).

${ }^{31}$ See, e.g., Donald J. Boudreaux \& A.C. Pritchard, Rewriting the Constitution: An Economic Analysis of the Constitutional Amendment Process, 62 FORDHAM L. REV. 111, 130 (1993) (noting that "a dominant political party may use its current electoral edge to 
been the levels of support necessary for parties to qualify for automatic access to the ballot and the numbers of signatures, the geographic distributional requirements, and the time schedules mandated for minor parties and independent candidates to achieve ballot access.

\section{CONSTITUTIONAL FrameWORK}

Before any discussion of the judicial treatment of suffrage-related regulations, a familiarity with the constitutional framework of the liberties related to the right to vote is necessary. Accordingly, this Part will present the basic constitutional parameters that empower the states to regulate ballot access, and through which the Supreme Court views the validity of such regulations. ${ }^{32}$

\section{A. State Control of Elections}

Conspicuously, the Constitution makes no mention of the fundamental right to vote or of the right to hold free elections. ${ }^{33}$ Because the Founding Fathers were unable to form a consensus on the issues of suffrage and election administration, the Constitution left the qualifications of voters in federal elections to be determined by the states. ${ }^{34}$ Thus, Article I, Section 2, Clause 1 of the Constitution states that "[ $t]$ he House of Representatives shall be composed of Members chosen every second year by the people of the several states, and the electors in each state shall have the qualifications requisite for the electors of the most numerous Branch of the state legislature." Similarly, the Seventeenth Amendment provides for the popular election of senators in the same manner as members of the

create a structural advantage that will assist the party in winning future elections"). Note however, that while statutory requirements often do not affect whether a major party will be on the ballot, such requirements may affect the candidate selected to represent the majority party by restricting access to a primary election. See supra note 26.

32 This Comment does not purport to constitute an extensive constitutional analysis of restrictions on the franchise, but rather will examine the Court's jurisprudence in one specific area-state ballot access restrictions.

${ }^{33}$ See BOTT, supra note 3, at 1 (discussing the consequences of the Founding Fathers' omission of the right to vote in the Constitution).

${ }^{34}$ See id. (stating that " [a]t the convention the Founding Fathers could not agree on who could vote, and as a result the Constitution left the qualifications of voters in federal elections to be determined by the states"); see also TRIBE, supra note 2, at 1084 (observing that " $[t]$ he Constitution endows the states with the power to determine qualifications for voting even in federal elections"). 
House of Representatives. ${ }^{35}$ Next, Article II, Section 1 provides that the method for choosing electors for president and vice president is substantially determined by the states, with Congressional influence limited to the establishment of a uniform time for the "chusing of Electors." Finally, Article I, Section 4, Clause 1 delegates to the states the power to regulate the "[ $t]$ he Times, Places and Manner of holding Elections for Senators and Representatives," subject to Congressional acquiescence. ${ }^{37}$

Accordingly, a facial reading of the Constitution seems to support the proposition that states were intentionally given a large degree of deference in the area of ballot access. This assertion may be bolstered by a review of the Framers' intent. For example, responding to criticism that leaving the state regulation of federal elections subject to congressional acquiescence might effectively subvert the state's authority, James Madison stated that "congressional controul will very probably never be exercised." He concluded that " $[t]$ he power [of congressional oversight] appears to me . . a as unlikely to be abused as any part of the constitution." ${ }^{38}$

${ }^{35}$ See TRIBE, supra note 2, at 1084 (noting the Seventeenth Amendment's impact on the manner in which Senators are elected). While the Constitution originally provided that state legislatures would elect Senators, the Seventeenth Amendment altered this scheme and provided, in relevant part, that " $[t]$ he electors in each State shall have the qualifications requisite for electors of the most numerous branch of the State legislatures." U.S. CoNST. amend. XVII, cl. 1.

${ }^{36}$ U.S. CONST. art. II, $\S 1, \mathrm{cl} .4$.

${ }^{37}$ U.S. CONST. art. I, $\S 4, \mathrm{cl}$. 2. Section 4 continues, stating that "Congress may at any time by law make or alter such Regulations, except as to the Places of chusing Senators." The Supreme Court has explicitly found this language to "invest[] Congress with broad power to regulate the entire spectrum of voting qualifications in congressional elections." TRIBE, supra note 2, at 1084-85 (citing Smiley v. Holm, 285 U.S. 355, 366 (1932)). Additionally, despite constitutional silence on the power of Congress to regulate presidential and vice-presidential elections, the Court has held that Congress "possesses the same power over such elections that it enjoys with respect to congressional elections." Id. at 1085 (citing Oregon v. Mitchell, 400 U.S. 112, 124 (1970)).

383 THE RECORDS OF THE FEDERAL CONVENTION OF 1787, at 311 (Max Farrand ed., 1911). However, as Madison's remarks were made in defense of the Constitution during debates in the Virginia Constitutional Convention, one should not overlook the possibility of exaggeration due to political posturing. See, e.g., John P. Roche, The Founding Fathers: A Reform Caucus in Action, 55 AMER. POL. SCI. REV. 799, 799 (1961) (noting that the Constitutional Convention was a social, interactive process and that the Federalist Papers presented a potentially misleading view that the Constitution was "designed"); Clinton Rossiter, Introduction to THE FEDERALIST at xvi (Clinton Rossiter ed., 1961) (observing that the Federalist Papers was a political instrument and must be read in view of this fact). For additional support that the Framers intended to grant the states great authority in the regulation of elections, see THE FEDERALIST No. 59, at 362 (Alexander Hamilton), No. 52, at 326 (James Madison) (Clinton Rossiter ed., 


\section{B. State Elections}

Federal authority to interfere in the regulation of state elections is implicated only by the "Republican Guarantee Clause." ${ }^{39}$ Consequently, the qualifications for voters in state elections are "the exclusive province of the state governments except insofar as they contravene the Constitution." 40 This exclusivity of state authority to regulate state elections is supported by the notion of dual sovereignty embodied in the Constitution. ${ }^{41}$ Because "[n]o function is more essential to the separate and independent existence of the States and their governments than the power to determine . . the qualifications of their own voters for state, county, and municipal offices and the nature of their own machinery for filling local public offices, ${ }^{12}$ the Supreme Court has long recognized the states' supremacy in this area.

\section{Other Constitutional Provisions}

While the states are given great deference to regulate federal and state elections, restrictions on the franchise must not contravene express constitutional guarantees. ${ }^{43}$ The constitutional provisions that implicate the rights of suffrage include: the Fifteenth Amendment, which bars racial restrictions; the Nineteenth Amendment, which bars restrictions based on gender; the Twenty-fourth Amendment, which bars poll taxes in federal elections; and the Twenty-sixth Amendment, which bars minimum voting ages in excess of eighteen years. ${ }^{44}$ In addition, regulations which inhibit the right to vote also

1961).

${ }^{39}$ Article $\Gamma$, Section 4 states in relevant part that "[t]he United States shall guarantee to every State in this Union a Republican Form of Government."

40 TRIBE, supra note 2, at 1085. See also Oregon v. Mitchell, 400 U.S. 112 (1970) (upholding the constitutionality of the Voting Rights Act Amendments of 1970 insofar as the Act prohibited the use of literacy tests in state elections and finding the Act to be a valid use of the enforcement clauses of the Fourteenth and Fifteenth Amendments and thereby within congressional authority).

${ }^{41}$ See, e.g., THE FEDERALIST No. 32, at 198 (Alexander Hamilton) (Clinton Rossiter ed., 1961) (stating that because "the plan of the convention aims only at a partial union or consolidation, the State governments would clearly retain all the rights of sovereignty which they before had, and which were not, by that act, exclusively delegated to the United States").

${ }_{42}$ Mitchell, 400 U.S. at 125 (quoting Justice Black, who delivered the opinion of the Court as to judgment only).

${ }^{45}$ See TRIBE, supra note 2, at 1085 (describing constitutional obstacles to state regulations).

${ }^{44}$ See id. 
implicate the First Amendment rights of association and free speech, as well as the Fourteenth Amendment rights to substantive due process and equal protection. ${ }^{45}$

\section{JUDICIAL TREATMENT: \\ PLUNGING INTO THE "POLITICAL THICKET"46}

While the Supreme Court has often recognized the right to vote as the most "precious" of all rights in a free society, this ultimate liberty is not explicitly guaranteed by the Constitution. ${ }^{47}$ Before an examination of the means by which the Court has chosen to protect this right may be undertaken, the "right" itself must be defined. Preliminarily, it must be noted that the entitlement which is commonly referred to as "the right to vote" substantively encompasses numerous distinct liberties which the Court has protected in varying degrees. These rights include: the citizen's opportunity to cast a vote, the community's ability to be represented within a larger polity, a racial group's entitlement to cast an effective and meaningful vote, the candidate's right to be placed on the ballot, and a constituent's chance to contribute to a particular candidate. ${ }^{48}$ While each of these rights affects distinct freedoms, they all similarly implicate the electoral process which is at the core of our "federal scheme of representative government."49 Nevertheless, because these fundamental rights were conspicuously omitted from the Constitution, the Court has struggled to define the precise quality and extent of these rights as well as the constitutional provisions with which to protect them. Accordingly, one constitutional scholar has observed that:

Given their essential character as parts of the election process, rights relating to the franchise stand poised between procedural due process, with its guarantee that an individual may participate

${ }^{45}$ See id.

${ }^{46}$ Colegrove v. Green, 328 U.S. 549, 556 (1946) (noting that ballot access restrictions were nonjusticiable political questions and stating that state action regarding the electoral process was a "political thicket" which the courts "ought not to enter").

${ }^{47}$ See Wesberry v. Sanders, 376 U.S. 1, 17 (1964) (stating that the Court has interpreted Art. I, Section 2 of the Constitution to give "persons qualified to vote a constitutional right to vote and to have their votes counted ${ }^{n}$ ).

${ }^{43}$ See TRIBE, supra note 2, at 1062; see also Gardner, supra note 3 (manuscript at 45, on file with the University of Pennsylvania Law Review) (discussing the many components of the right to vote for which litigants have sought constitutional protection).

${ }^{49}$ TRIBE, supra note 2, at 1062. 
in the application of general rules to that individual's particular situation, and the $[\mathrm{F}]$ irst $[\mathrm{A}]$ mendment, with its guarantee that an individual be allowed to participate in the most general communicative processes that determine the contours of our social and political thought. At the same time, election-related rights display the special feature that the equality with which they are made available, rather than the fact of their availability or absence, ordinarily proves decisive..$^{50}$

This Part will assess the Court's jurisprudence in the area of state ballot access restrictions-one small facet of the more general rubric of the "right to vote"-and shall demonstrate that the Court's struggles in this area have failed to clarify both the dimensions of the rights implicated as well as the process by which those rights should be examined.

Prior to 1968, the Court had declined to address the constitutional issue of state-imposed restrictions to ballot access for third parties and independent candidates. ${ }^{51}$ However, in Williams $v$. Rhodes, the Court accepted jurisdiction and found an Ohio election law that rendered it "virtually impossible" for third parties to be placed on state ballots to choose electors for presidential elections as violative of the Equal Protection Clause of the Fourteenth Amendment. ${ }^{52}$ Since this initial foray into the area of ballot access, the Court has ruled on the constitutionality of a number of state election schemes. However, as this Part will demonstrate, the Court has failed to articulate a consistent analytical standard with which to evaluate state ballot access restrictions, appearing instead to rely on distinct standards in each case. ${ }^{53}$

\section{A. Williams and the "Early" Cases}

As Tribe has observed, the "Court's initial forays into the realm of access requirements were oblique and not wholly consistent." Nevertheless, the common denominator of these "early" cases was the Court's attempt to employ a standard of analysis that would be

${ }^{50} \mathrm{Id}$. (footnotes omitted).

${ }^{31}$ See, e.g., Porto, supra note 14, at 288 (stating that "federal courts avoided the issues raised in [the legal challenges posed by non-traditional candidates to ballot access restrictions] until 1968"); Smith, supra note 14, at 174 (describing the Court's decision in Williams v. Rhodes, 393 U.S. 23 (1968), as a "new twist" in ballot access laws).

${ }^{32}$ See Williams, 393 U.S. at 24-25, 34.

${ }^{5 s}$ See Porto, supra note 14, at 281; Smith, supra note 14, at 186-87.

54 TRIBE, supra note 2, at 1102. 
compatible with its other equal protection jurisprudence. This Section will illustrate the difficulties faced by the Court in this effort, emphasizing in particular the inconsistencies and creative interpretations employed as the Court addressed the issues unique to each case. In short, this Section will serve as an introduction to the "doctrinal enigmas that bedevil the law of ballot access."

\section{Williams v. Rhodes}

In Williams $v$. Rhodes, the Court found a highly restrictive Ohio election scheme violative of the Equal Protection Clause of the Fourteenth Amendment. ${ }^{56}$ Because many subsequent opinions "professed their fidelity to the paradigm supposedly enunciated in Williams, ${ }^{257}$ it will be instructive to analyze the issues addressed in Williams in considerable detail. The Ohio Election Code required any new political party desiring to be placed on the general election ballot to file petitions signed by qualified electors totaling fifteen percent of the number of ballots cast in the preceding gubernatorial election. However, the existing Republican and Democratic Parties were automatically placed on the ballot if they received in excess of ten percent of the vote in the preceding gubernatorial election. ${ }^{58}$

The code also imposed many other substantial burdens that made it "virtually impossible for any party to qualify for the ballot except the Republican and Democratic Parties." ${ }^{.59}$ One result was that the

${ }^{35} I d$.

${ }^{36}$ See 393 U.S. at 23.

${ }^{57}$ TRIBE, supra note 2, at 1103.

${ }^{58}$ See Williams, 393 U.S. at 24-26.

${ }^{59}$ Id. at 25 . The Williams Court noted that in addition to the $15 \%$ signature requirement, the following burdens were imposed upon prospective third parties:

1. At the primary election, the new party was required to elect a state central committee consisting of two members from each congressional district and county central committees for each county of Ohio. See id. at $25 \mathrm{n} .1$ (citing relevant Ohio Code sections).

2. At the primary election, the new party was required to elect delegates and alternates to a national convention. Because a candidate was prohibited from seeking the office of delegate to the national convention or committeeman if he voted as a member of a different party at a primary election in the preceding four-year period, the new party was required to have over twelve hundred members who would be willing to serve as committee members and delegates, none of whom had previously voted in another party's primary. See id.

3. The candidates for nomination in the primary would be required to file petitions signed by qualified electors. See id.

4. The Court also noted that a section of the Ohio code provided that a qualified elector at a primary election was one who: a) voted for a majority of that party's candidates at the last election, or b) had never voted in any election before. Since 
Ohio American Independent Party and the Socialist Labor Party were required to file their petitions for inclusion on the Ohio presidential ballot two months before the Republican and Democratic primaries and nine months before the general election. ${ }^{60}$ The Independent Party obtained in excess of the 433,100 signatures required, but failed to meet the early filing deadline. The Socialist Labor Party, despite having been in existence since 1892, retained only 108 members in Ohio and fell far short of the fifteen percent petition requirement. ${ }^{61}$ The parties brought suit, alleging that the filing deadline and the complex primary regulations denied new parties and their supporters the equal protection of the laws guaranteed by the Fourteenth Amendment. ${ }^{62}$

As an initial matter, the Court summarily accepted jurisdiction, defining the issue presented as a "justiciable controversy." Court then noted that, while Article II, Section 1 of the Constitution empowers each State to "appoint, in such Manner as the Legislature thereof may direct, a Number of Electors' . . . to choose a President and Vice President," this in no way granted states the power to pass laws regulating elections that violate any express provision of the Constitution. ${ }^{64}$

The Court asserted that the Ohio election laws infringed the "right of individuals to associate for the advancement of political beliefs" as well as the right of qualified voters to "cast their votes effectively." 65 Because both of these rights "rank among our most

neither of the plaintiffs in Williams "had any candidates at the last preceding regular state election, they would ... [ [be forced] to seek out members who had never voted before to sign the[ir] nominating petitions" and only these individuals could vote in the new primary. See id.

${ }^{60}$ See id. at 26-27.

${ }^{61}$ See id. at 40.

62 See id. at 26.

${ }^{63}$ Id. at 28 ("These cases do raise a justiciable controversy under the Constitution and cannot be relegated to the political arena."). Notably, the Court cited the then recently decided Baker v. Carr, 369 U.S. 186 (1962), as demonstrative of the nonpolitical character of the issue. In finding a Tennessee legislative apportionment scheme to be violative of equal protection, the Court in Baker announced a series of factors which, if present, would render an issue solely political. But see Todd J. Zywicki, Federal Judicial Review of State Ballot Access Regulations: Escape from the Political Thicket, 20 T. MARSHALl L. REV. 87, 125-33 (1994) (noting that the Court, flush with success from the reapportionment cases, acted improperly in accepting jurisdiction and "blundering" into the area of ballot access law). In Colegrove v. Green, 328 U.S. 549,556 (1946), the Court had announced that the electoral process was a "political thicket" which the courts "ought not to enter."

${ }^{64}$ Williams, 393 U.S. at 29 (quoting U.S. CoNST. art. II, § 1, cl. 2).

${ }^{65} \mathrm{Id}$. at 30 . 
precious freedoms"66 and are thus "fundamental rights," the court stated that "only a compelling state interest [could] justify limiting ${ }^{\prime 67}$ such freedoms. ${ }^{68}$ While commentators have been quick to assert that the Court in Williams simply applied strict scrutiny, ${ }^{69}$ it is significant to note that the Court did not discuss the question of narrow tailoring-traditionally, an integral facet of a strict scrutiny analysis. Perhaps the Court's failure to identify any "compelling" state interest rendered the question of a less restrictive, equally effective legal scheme moot. Nevertheless, as future cases indicate, the Court's declining to articulate the full strict scrutiny standard may have been a deliberate maneuver to maintain a less restrictive analysis in the area of ballot access jurisprudence.

In Williams, Ohio asserted four distinct interests served by the access restrictions. First, the state argued that maintaining the integrity of the two-party system and encouraging political stability justified such a scheme. In rejecting this claim, the Court noted that the Ohio system did not merely favor a two-party system, but rather favored "two particular parties-the Republicans and the Democrats-and in effect tend[ed] to give them a complete monopoly."70 Thus, the Court did not repudiate the theoretical supposition that support of a two-party system could reach the level of a "compelling" state interest capable of outweighing even the most fundamental individual liberties. Rather, the Court found that in this particular

${ }^{66} I d$.

${ }^{67} \mathrm{Id}$. at 31 (quoting NAACP v. Button, 371 U.S. 415, 438 (1963)).

${ }^{68}$ For the Court's treatment of the freedom of association as a fundamental right, see United Mine Workers v. Illinois Bar Ass'n, 389 U.S. 217 (1967), NAACP v. Button, 371 U.S. 415 (1963), and NAACP v. Alabama ex rel. Patterson, 357 U.S. 449 (1958). Additionally, the Court has asserted that "[n]o right is more precious in a free country than that of having a voice in the election of those who make the laws under which, as good citizens, we must live. Other rights, even the most basic, are illusory if the right to vote is undermined." Williams, 393 U.S. at 31 (quoting Wesberry v. Sanders, 376 U.S. 1, 17 (1964)). See also Yick Wo v. Hopkins, 118 U.S. 356, 370 (1886) (stating that the right to vote is a "fundamental political right, because [it is] preservative of all rights"). These rights are protected against encroachment by the states via the Fourteenth Amendment.

Notably, the cases discussed in this Comment concern state regulations which have served to restrict candidates and parties from access to the ballot. Accordingly, the Court's analysis in these cases typically confines itself to infringements of the right to vote. A related area of the law that remains outside the scope of this Comment concerns state action restricting the formation of political organizations. This latter area of jurisprudence deals to a greater extent with infringements on the right of association.

${ }^{69}$ See, e.g., Porto, supra note 14, at 290.

70 Williams, 393 U.S. at 32. 
instance, the election scheme went beyond advocating a two-party system and promoted two distinct entities and two unique ideological philosophies to the exclusion of all others. As a result of such a finding, the Court's analysis reads like a traditional discussion of the benefits of free speech, stating that "[c]ompetition in ideas and governmental policies is at the core of our electoral process and of the First Amendment freedoms." ${ }^{\text {"1 }}$ The Court concluded that new parties must have the freedom to organize and to compete in this marketplace of ideas. ${ }^{72}$

Next, Ohio asserted its right to ensure that the winner of an election be supported by the majority of voters. While conceding that this may indeed be a legitimate state interest, the Court explained that allowing the state to keep all political parties off the ballot until they had enough support to win an election would "stifle the growth of all new parties working to increase their strength."73 Similarly, Ohio's interest in providing potential third-party supporters with choices in leadership and ideology was not effectuated by the legislative scheme. ${ }^{74}$

Finally, the Court rejected Ohio's claim that the restrictive provisions were justified to maintain a simple and orderly ballot for the purpose of eliminating voter confusion. The Court replied that, although the existence of "multitudinous fragmentary groups might justify some regulatory control," 75 in the instant case, the danger was "no more than "theoretically imaginable""76 and no such remote

${ }^{71} I d$.

${ }^{72}$ For an interesting discussion of the "marketplace of ideas" theory of the First Amendment, see C. Edwin Baker, The Process of Change and the Liberty Theory of the First Amendment, 55 S. CAL. L. REV. 293, 300 (1981) (stating that "[t]he traditional marketplace of ideas theorist claims that truth is a proper guide to how we should organize society, and that the first amendment protection of the free trade of ideas will advance us toward truth" but criticizing this theory as not "provid[ing] adequate scope for the means needed for fundamental, progressive change").

${ }^{73}$ Id. In fact, the restriction was a response to the results of the 1948 Ohio presidential election. In 1948, the Ohio election code required third-party candidates to secure signatures of only one percent of the registered voters. As a result, Henry Wallace was placed on the ballot and prevented both Harry Truman and Thomas Dewey from winning a majority of the popular vote cast. See BOTT, supra note 3, at 95.

${ }^{74}$ Ohio had argued that requiring a new political party to maintain an elaborate party structure and to organize a primary election ensured that supporters of the new party's ideology would be able to choose from among various alternative spokespersons for their ideas. The Court noted that, because no minor party could meet the requirements, the true result was that "the Ohio system thus denie[d] the 'disaffected' not only a choice of leadership but [also] a choice on the issues as well." Williams, 393 U.S. at 33.

${ }^{75}$ Id. (emphasis added).

${ }^{76}$ Id. (quoting United Mine Workers v. Illinois Bar Ass'n., 389 U.S. 217, 224 
danger could justify infringing the fundamental rights of association and effective voting. Therefore, the Court found that the Ohio laws imposed "invidious discrimination" violative of the Equal Protection Clause. ${ }^{77}$

In a lengthy dissent, Justice Stewart averred that:

[i]n view of the broad leeway specifically given the States by Article II, Section 1, of the Constitution [in selecting presidential electors], it seems clear to me that the basic standard of constitutional adjudication under the Equal Protection Clause ... is the most stringent test that properly can be held applicable here."

Stewart argued that the Court should apply a mere rational basis test, asserting that " $[t]$ he constitutional safeguard is offended only if the classification rests on grounds wholly irrelevant to the achievement of the State's objective. . . . A statutory discrimination will not be set aside if any state of facts reasonably may be conceived to justify it."'79 Justice Stewart concluded that because the classification was "clear[ly]" relevant to the achievement of the state's legitimate objective, the election law was constitutional. ${ }^{80}$

\section{Jenness v. Fortson: A Retreat from Strict Scrutiny}

Two years after dissenting from the Court's finding that the Ohio election law was unconstitutional in Williams, Justice Stewart wrote the majority opinion as the Court evaluated Georgia's ballot access law in Jenness v. Fortson. ${ }^{81}$ The Georgia Election Code provided that any candidate who had not entered and won a primary election of a "political party" could only gain access to the general election ballot by filing a nominating petition "signed by at least $5 \%$ of the number

(1967)).

77 Id. at 34. Commentators have noted that "the nature of the constitutional rights implicated and the propriety and urgency of the state interests articulated [in Williams] remained shrouded beneath a veneer of doctrinal generalizations." TRIBE, supra note 2, at 1103 . The rationale for this criticism is that Williams was an "easy" case because the Ohio legislative scheme made it "virtually impossible for a new political party . . . to be placed on the state ballot" and was decided hastily due to the impending elections. Id d. at 1102-03 (quoting Williams, 393 U.S. at 24). In its rush to judgment, the Court may have treated the constitutional issues cavalierly. See id.

${ }_{78}$ Williams, 393 U.S. at 51 (Stevens, J., dissenting).

${ }^{79}$ Id. (quoting McGowan v. Maryland, 366 U.S. 420, 425-26 (1961)).

${ }^{80} \mathrm{Id}$. at 53.

81403 U.S. 431 (1971). Commentators have noted that, "[a]s thesis and antithesis, Williams and Jenness frame the relevant issues" inherent in the ballot access debate. TrIBE, supra note 2, at 1102 . 
of registered voters at the last general election for the office in question." 82

In rejecting the appellants' First and Fourteenth Amendment challenges, the Court rested its judgment on the fundamental finding that the Georgia electoral system "in no way [froze] the [political] status quo." ${ }^{83}$ Justice Stewart, writing for a unanimous Court, arrived at this result principally by distinguishing the decision in Williams. $^{84}$ Justice Stewart, finding that "nothing [in the Georgia election system] abridg[ed] the rights of free speech and association," declined to invoke strict scrutiny and recognized the state's interest

${ }^{82}$ Jenness, 403 U.S. at 432 (citing GA. CODE ANN. \$ 34-1010 (1970)). The Georgia Election Code provided that "[a]ny political organization whose candidate received $20 \%$ or more of the vote at the most recent gubernatorial or presidential election is a "political party." Id. at 433 (citing GA. CODE ANN. § 34-103(u)). Any other political organization was defined as a "political body." See id. (citing GA. CODE ANN. § 34103(s)). "Political parties" were permitted to conduct primary elections regulated by state law. The winner of the primary was placed on the ballot of the general election as the nominee of the party. See id. (citing GA. CODE ANN. \$\$ 34-104 to -1006, -1008, $-1009,-1014,-1015,-1102,-1301$ to $-1303,-1308,-1507,-1513)$. Alternatively, a nominee of a "political body" or an independent candidate could have her name placed on the general election ballot by filing a nominating petition. See id. (citing GA. CODE ANN. § 34-1001). The petition required signatures of at least five percent of the total number of electors eligible to vote in the last election for the office the candidate was seeking. The filing deadline was the same as that required of a candidate filing in a party primary. See id. at 433-34 (citing GA. CODE ANN. § 34$1010(\mathrm{e}),-1010(\mathrm{~b}))$.

${ }^{83}$ Jenness, 403 U.S. at 439. The appellants included the Georgia Socialist Workers Party's nominee for Governor and two nominees for the House of Representatives.

${ }^{84}$ Justice Stewart stated that, in serving the state's interest, Georgia's election scheme did not unduly restrict ballot access. Justice Stewart noted the following differences between the Ohio restrictions in Williams and the Georgia regulations: 1) Georgia freely provided for write-in votes; 2) Georgia did not require every candidate to be the nominee of a political party, but recognized independent candidates; 3) Georgia did not fix an unreasonably early deadline for filing signature petitions by candidates not endorsed by established parties; 4) Georgia did not require small and new parties to establish "elaborate primary election machinery"; 5) Georgia allowed voters to sign a petition for a third-party candidate despite having signed the petition of an independent candidate; and 6) Georgia did not require petition signatures to be notarized. See id. at 438-39. 
in avoiding voter confusion to justify the requirements. ${ }^{85}$ Justice Stewart noted that:

There is surely an important state interest in requiring some preliminary showing of a significant modicum of support before printing the name of a political organization's candidate on the ballot-the interest, if no other, in avoiding confusion, deception, and even frustration of the democratic process at the general election. ${ }^{86}$

\section{Intermediate Scrutiny: Storer v. Brown and American Party v. White}

The Court's incongruous opinions in Williams and Jenness generated significant uncertainty concerning the constitutionality of state ballot access restrictions. The Court's subsequent opinions in Storer v. Brown ${ }^{87}$ and American Party v. White ${ }^{88}$ not only failed to clarify the jurisprudence, but also exacerbated the problem.

Four years after the decision in Jenness, the Court examined First and Fourteenth Amendment challenges to five provisions of the California Election Code in Storer v. Brown. ${ }^{89}$ In assessing the constitutionality of the state's disaffiliation requirement, the Court creatively reinterpreted its decision in Williams as one that recognized

85 Id. at 440 . Given its previous analysis in Williams, the Court's assessment in Jenness has been described as "striking." See Smith, supra note 14, at 181, 185 ("While the Georgia law was not as restrictive as the statute struck down in Williams, the difference was not so great as the Jenness Court tried to make it appear."). Smith asserted that "because Jenness found compelling those same state interests that Williams specifically rejected, this element of the decision approached outright reversal. ${ }^{n} I d$. at 185. Smith noted that "it is surprising that five Justices who had voted in Williams to strike down the Ohio law voted in Jenness to uphold the Georgia law." Id.; see also Zywicki, supra note 63, at 113 (stating that "the Court retreated dramatically in Jenness").

${ }^{86}$ Jenness, 403 U.S. at 442.

87415 U.S. 724 (1974).

88415 U.S. 767 (1974).

${ }^{89}$ Storer, 415 U.S. at 726-27. Independent congressional, presidential and vicepresidential candidates essentially challenged two effects of the regulations: 1) a disaffiliation restriction that denied ballot access to independent candidates who had voted in the immediately preceding primary or registered with a qualified political party within one year prior to the preceding primary; and 2) the aggregate effect of several nominating petition regulations that required independent candidates to secure signatures of at least five percent of the voters in a 24-day period and prohibited signatures from persons who had voted in the primary elections. See id. (citing CAL. ELEC. CODE $\$ \S 6830$ (c), 6830(d), 6831, 6833, 6830(c) (Supp. 1974)). 
the states' substantial interests in encouraging compromise and stability, in attempting to ensure that the election winner represented a majority of the community, and in avoiding voter confusion. ${ }^{90}$ In fact, the Court asserted that the Williams decision "inferred that 'reasonable requirements for ballot position' ... would be acceptable." 91

In holding the disaffiliation requirement constitutional, the Court cited the state's compelling interest in furthering the stability of its political system as outweighing the interest of the candidates and their supporters. ${ }^{92}$ Significantly, however, the Court did not discuss whether such a "compelling" interest was necessary to overcome the individual rights infringed and did not undertake an inquiry into the availability of relatively less restrictive alternative means of ensuring such political stability-traditional hallmarks of a strict scrutiny analysis. Thus, the Court seemed to employ a standard less exacting than strict scrutiny. ${ }^{93}$

In addition, the Court cited Bullock v. Carter as support for the state's legitimate interest in "sprotect[ing] the integrity of its political processes." T4 The Court explained that "[a]lthough we have no way of gauging [the level of ballot overcrowding] if access to the ballot were unimpeded ... we are bound to respect the legitimate objectives of the State." "95 Thus, the Court evidently abandoned its position in Williams that held merely "theoretically imaginable"" dangers to be insufficient to warrant infringement of the right of association and the right to vote. ${ }^{96}$

The same day the Court decided Storer, it also assessed the constitutionality of various aspects of the Texas election system in American Party v. White. ${ }^{97}$ The Court remained "wholly unpersuad-

90 See id. at 729.

${ }^{91}$ Id. (quoting Williams, 393 U.S. at 32).

${ }_{92}$ See id. at 736.

${ }^{93}$ See TRIBE, supra note 2, at 1107 (noting that "[t]he most baffling aspect of ... Storer was the standard of review being applied" and commenting that both Storer and American Party employed standards "far less demanding" than strict scrutiny); see also Fred H. Perkins, Note, Better Late Than Never: The John Anderson Cases and the Constitutionality of Filing Deadlines, 11 HOFSTRA L. REv. 691, 703 (1983) (finding that "[a]lthough the Court has never clearly distinguished [its standards of review], the overall reasoning process of [the ballot access cases] reveal [sic] that the Court is often not rigidly applying the standard that it enunciates").

${ }^{94}$ Storer, 415 U.S. at 733 (quoting Bullock v. Carter, 405 U.S. 134, 145 (1972)).

${ }^{95}$ Id. at 732 (quoting Bullock, 405 U.S. at 145).

${ }^{96}$ Williams, 393 U.S. at 33 (quoting United Mine Workers v. Illinois Bar Ass'n, 389 U.S. 217, 224 (1967)).

97415 U.S. 767 (1974). Minority political parties, their candidates and supporters, 
ed" that the Texas scheme discriminated against third parties and independent candidates in violation of the Equal Protection Clause, finding the claims wholly "without merit." that the convention and petition process was no more burdensome to third parties and independent candidates than primary elections, run-off elections and party conventions were to major parties. ${ }^{99}$ Notably, the Court stated that the requirements were "constitutionally valid measures, reasonably taken in pursuit of vital state objectives that cannot be served equally well in significantly less burdensome ways." 100 Consequently, with respect to these particular requirements, the Court seemed to inquire into the relative restrictiveness of alternative measures. However, in its entirety, the standard employed by the Court fell short of pure strict scrutiny.

Overall, the Court's opinion in American Party demonstrates the Court's almost ad hoc determination of the relative constitutionality of various provisions of the Texas Election Code. ${ }^{101}$ In affirming

and independent candidates challenged a one percent support requirement as well as regulations mandating precinct conventions and petition conditions. In addition, petitioners challenged a preprimary ban on petition circulation, the disqualification of voters who had participated in other parties' nominating processes from signing petitions, a 55-day limitation on securing signatures, and a requirement that all signatures be notarized. See id. at 779 (citing TEX. ELEC. CODE arts. 13.12, 13.45(1) (1967 \& Supp. 1973)).

98 Id. at 780-81.

${ }^{99}$ See id. at 781.

${ }^{100} \mathrm{Id}$.

${ }^{101}$ The Court rejected the petitioners' claim that the one percent support requirement was invidious, citing the state's "admittedly vital interests ... that political parties appearing on the general ballot demonstrate a significant, measurable quantum of community support" and observing that two of the petitioners had met the requirement. Id. at 782, 783-84. The Court also rejected the petitioners' argument that the disqualification of primary voters from signing ballot petitions was unconstitutional. The Court felt that this requirement merely acted to prevent voters from essentially voting twice in the primary process, finding that "the State may determine that it is essential to the integrity of the nominating process to confine voters to supporting one party and its candidates in the course of the same nominating process." Id. at 786. Similarly, the Court found that the 55-day time limit was not "too onerous" and that the notary requirement was the only means available to the state to ensure that voters did not vote twice for the same office. Id. at 787 .

Next, the Court upheld the validity of the signature requirement for independent candidates despite the fact that candidates were permitted only 30 days in which to gather them. See id. at 788-89. Likewise, the Court affirmed the constitutionality of the Texas statute that authorized public financing of the costs incurred by the major political parties in the primary process but made no provision for the financing of minor parties and independents. The Court opined that a state is not required to "finance the efforts of every nascent political group seeking to organize itself." Id. at 794. Finally, the Court remanded for further consideration the state's practice of 
the dismissal of declaratory and injunctive relief sought by petitioners, the Court clearly entertained more than a mere rational basis test, but fell far short of the probing analysis indicative of strict scrutiny in other areas of jurisprudence. ${ }^{102}$

\section{Filing Fees: Bullock v. Carter and Lubin v. Panish}

During the time period that the Supreme Court decided Storer and American Party, it also decided two cases in which state regulations imposed a filing fee as a prerequisite to ballot access. In Bullock v. Carter, the Court examined a Texas statute that required the payment of a filing fee as an absolute prerequisite to a candidate's participation in a primary election. ${ }^{103}$

As an initial matter, the Court directly assessed the standard of review appropriate to analyze the issues at hand. Chief Justice Burger, writing the opinion for the Court, observed that the Court had never considered candidacy itself as a distinct fundamental right sufficient to invoke heightened scrutiny. ${ }^{104}$ However, because the exclusionary nature of the filing fees directly and purposefully affected the ability of voters to exercise their rights of suffrage, Justice Burger found a heightened level of scrutiny to be appropriate. Accordingly, Justice Burger stated that:

Because the Texas filing-fee scheme has a real and appreciable impact on the exercise of the franchise, and because this impact is related to the resources of the voters supporting a particular candidate, we conclude ... that the laws must be "closely scrutinized" and found reasonably necessary to the accomplishment of legitimate state objectives in order to pass constitutional muster. ${ }^{105}$

While this level of review is certainly greater than the mere rationality required in Jenness, it is nonetheless arguably less strict than the scrutiny employed by the Court in Williams ${ }^{106}$ and certainly less rigorous than a pure strict scrutiny as applied in cases such as

printing only the two major established political parties on absentee ballots. See id. at 794-95.

${ }^{102}$ For example, see the reapportionment cases of Karcher v. Dagget, 462 U.S. 725 (1983) (finding that a New Jersey reapportionment plan that was insufficiently reflective of the population deprived citizens of equal representation) and Reynolds $v$. Sims, 377 U.S. 533 (1964) (finding that malapportionment of Alabama state electoral districts denied citizens equal protection of the laws).

${ }^{103}$ See 405 U.S. 134, 136 (1972).

${ }^{104}$ See id. at 142-43.

${ }^{105} \mathrm{Id}$. at 144 (emphasis added).

${ }^{106}$ See Porto, supra note 14, at 297. 
Brown v. Board of Education. ${ }^{107}$ Most notably, the Court in Bullock merely required a legitimate state interest, whereas the Court in Williams required a compelling state interest. The Court in Bullock recognized two legitimate state interests furthered by the filing fees, but nevertheless ultimately concluded that the Texas filing fees were unconstitutional. ${ }^{108}$ Similarly, in Lubin v. Panish ${ }^{109}$ the Court assessed the constitutionality of a California statute that required the payment of a filing fee in order to be placed on the ballot in the primary election. ${ }^{110}$ The Court declared that the state's legitimate interest in eliminating frivolous candidates from the ballot "must be achieved by a means that does not unfairly or unnecessarily burden either a minority party's or an individual candidate's equally important interest in the continued availability of political opportunity."111 Thus, the Court in Lubin held that conditioning candidacy solely on the basis of ability to pay without providing any alternative means of securing access to the ballot was "not reasonably necessary to the accomplishment of the State's legitimate election interests." 112

The Court reasoned that a filing fee was simply an inaccurate method of determining a candidate's "seriousness" and recommended that states utilize a system of nominating petitions to test a potential candidate's level of popular support. In reaching this result, the Court interpreted its holding in Bullock as "expressly reject[ing] the validity of filing fees as the sole means of determining a candidate's 'seriousness.'"113 Thus, although the Court in Bullock

107347 U.S. 483,495 (1954) (finding that racially segregated educational facilities were "inherently unequal").

${ }^{108}$ See Bullock, 405 U.S. at 149. The Court found that the filing fees were "extraordinarily ill-fitted" to protecting the state's legitimate interest in regulating the number of candidates on the ballot and also determined that Texas' other legitimate interest furthered by filing fees-apportioning the cost of primary elections to those candidates who participated-was not "necessary." See id. at 144-49 (stating that filing fees were not "necessary" because the election could be funded from the state's general treasury). In finding the Texas system unconstitutional, the Court cautiously limited the holding to the "salient" features of the case and emphasized that the result in no way "cast doubt on the validity of reasonable candidate filing fees." Id. at 149 (emphasis added).

${ }^{109} 415$ U.S. 709 (1974).

${ }^{110}$ See id. The petitioner in Lubin was an indigent who was unable to pay the filing fee of $\$ 701.60$, and admittedly would have been unable to pay a filing fee of as little as $\$ 1$. See id. at 710,714 .

111 Id. at 716.

${ }^{112}$ Id. at 718 .

113 Id. at 716 . 
had stated unambiguously that "reasonable" filing fees would certainly be valid, Lubin evidently stands for the proposition that a filing fee of any amount is "unreasonable" if the potential candidate is not presented with an alternative to paying the filing fee. ${ }^{114}$

\section{Return to Strict Scrutiny?:}

\section{Illinois State Board of Elections v. Socialist Workers Party}

In assessing the constitutionality of several provisions of the Illinois Election Code in Illinois State Board of Elections v. Socialist Workers Party, ${ }^{115}$ the Court once again utilized a heightened standard of review, employing the "clearest example of strict scrutiny" since Williams. ${ }^{116}$

Writing for a unanimous Court, Justice Marshall observed that " $[r]$ estrictions on access to the ballot burden two distinct and fundamental rights, 'the right of individuals to associate for the advancement of political beliefs, and the right of qualified voters . . to cast their votes effectively." "117 Because such "vital individual rights" were implicated, the Court declared that a state regulation could only be constitutional if the "classification [was] necessary to serve a compelling [state] interest."118 Whereas the opinion in Illinois State Board of Elections is certainly notable for its employment of this strict scrutiny standard, the case is truly remarkable for the fact that Justice Marshall cited American Party v. White, Storer v. Brown, and Williams $v$. Rhodes as direct support for this standard. ${ }^{119}$ As discussed above, the Court in American Party found the state regulations to be "constitutionally valid measures, reasonably taken in pursuit of vital state objectives." 120 Similarly, while the Court in Storer found the

${ }^{114}$ Although Justice Douglas regarded the entire case as one concerning wealth discrimination, see id. at 719 (Douglas, J., concurring), the majority concluded by citing Jenness for the proposition that "[t] he point, of course, is that ballot access must be genuinely open to all, subject to reasonable requirements." Id. at 719 (citing Jenness v. Forston, 403 U.S. 431, 439 (1971)).

${ }^{115} 440$ U.S. 173 (1979).

${ }^{116}$ Porto, supra note 14, at 299.

${ }^{117}$ Illinois State Bd. of Elections, 440 U.S. at 184 (quoting Williams v. Rhodes, 393 U.S. 23, 30 (1968)).

${ }^{118}$ Id.

${ }^{119}$ See id. at 184. But see Justice Blackmun's concurrence, which emphasizes an "unrelieved discomfort" at the Court's continued adherence to the conclusory analysis inherent in the leveled scrutiny structure, and states that the phrases of "compelling [state] interest," and "least drastic [restrictive] means" are "not very helpful for constitutional analysis." Id. at 188-89 (Blackmun, J., concurring).

${ }^{120}$ American Party v. White, 415 U.S. 767,781 (1974) (emphasis added). 
state's "interest in [furthering] the stability of its political system" to outweigh the interest of the candidates and their supporters, ${ }^{121}$ the Court did not address the strength of the relationship between the regulation and the state objective demanded of a constitutionally valid scheme. Quite to the contrary, the Court in Storer seemed to rest its holding on a finding that the California Code's disaffiliation requirement did not discriminate against independents because it also prohibited party candidates from registering with another party within one year of candidacy declaration. ${ }^{122}$ Lastly, although the Court in Williams found that "only a compelling state interest ... can justify limiting'" fundamental freedoms, again the Court did not address the degree of relationship required between the state election scheme and the state interest to be furthered. ${ }^{123}$

In Illinois State Board of Elections, the Court observed that the petitioning requirement furthered the state's "legitimate" interest in assuring that the winner of an election represents the majority of voters. ${ }^{124}$ However, the Court then declared that when furthering a legitimate interest, "a State may not choose means that unnecessarily restrict constitutionally protected liberty"125 and cited Lubin for the proposition that "[s]tates [must] adopt the least drastic means to achieve their ends." ${ }^{\text {26 }}$ While the Court in the past had essentially failed to require state regulations to be narrowly tailored to meet state interests in the context of ballot access restrictions, it now asserted that Lubin $^{127}$ demanded no less. Not surprisingly, the Court ultimately found that the disparate signature requirements in the Illinois Election Code violated the Equal Protection Clause and were thus invalid. ${ }^{128}$

${ }^{121}$ Storer v. Brown, 415 U.S. 724, 736 (1974).

122 See id. at 734.

123 See Williams v. Rhodes, 393 U.S. 23, 31 (1968) (quoting NAACP v. Button, 371 U.S. 415,438 (1963)).

${ }^{124}$ See Illinois State Bd. of Elections, 440 U.S. at 184-85.

${ }^{125}$ Id. at 185 (quoting Kusper v. Pontikes, 414 U.S. 51, 58-59 (1973) (finding invalid an Illinois statute that prohibited a person from voting in primaries of different parties unless a 24-month waiting period had elapsed)).

${ }^{126} I d$.

127 See supra notes 113-114 and accompanying text (suggesting that Lubin was arguably a case more concerned with wealth discrimination than ballot access).

${ }^{128}$ See Illinois State Bd. of Elections, 440 U.S. at 186-87. The Court compounded the confusion inherent in this decision by failing to explicitly identify a "compelling" state interest. As discussed above, the Court merely alluded to a state's "legitimate interest in regulating the number of candidates on the ballot." Id. at 184-85. However, because the Court proceeded to inquire as to whether the state law represented the "least drastic" means to achieve the state objective, the opinion presumably implied 


\section{B. Emergence of a Balancing Test: Anderson v. Celebrezze and Subsequent Cases}

Four years after creatively knitting together precedent to construct a heightened standard of review sufficient to find the Illinois nominating petitions in Illinois State Board of Elections as violative of equal protection, the Court utterly abandoned the use of tiered scrutiny and equal protection analysis in favor of a balancing test and due process analysis in Anderson v. Celebrezze. ${ }^{129}$ Instead of clarifying ballot access jurisprudence once and for all, Anderson seemed only to add to the confusion.

\section{Anderson v. Celebrezze}

In Anderson, an independent candidate for president of the United States challenged an Ohio statute which required independent candidates to file a statement of candidacy and nominating petition in March in order to qualify for the general election ballot in November. ${ }^{130}$ The candidate, who ultimately secured $5.9 \%$ of the popular vote cast in Ohio and $6.6 \%$ of the popular vote cast in the nation, challenged the early filing deadline as violative of his First and Fourteenth Amendment rights.

As in previous cases, the Court initially observed that while the filing deadline affected candidates' rights, the requirement inevitably implicated the rights of voters as well. Writing for the five member majority, Justice Stevens asserted that it "is beyond debate that freedom to engage in association for the advancement of beliefs and ideas is an inseparable aspect of the 'liberty' assured by the Due Process Clause of the Fourteenth Amendment, which embraces freedom of speech." ${ }^{n 131}$ The Court then explicitly stated that it would base its conclusions directly on the First and Fourteenth Amendments and would not "engage in a separate Equal Protection Clause analysis."132 Nevertheless, the Court continued to rely on its previous jurisprudence in this area, citing Williams, Bullock, Lubin

that the state's interest had met the first requirement of strict scrutiny-a compelling interest. Id. at 185. Consequently, Illinois State Board of Elections appears to indicate that maintaining a manageable number of names on the ballot is indeed a "compelling" state interest.

${ }_{129}$ See 460 U.S. 780 (1983).

${ }^{130}$ See id. at 782-83 (citing OHIO REV. CODE ANN. \$ 3513.25 .7 (Supp. 1982)).

${ }^{131} \mathrm{Id}$. at 787 (quoting Justice Harlan in NAACP v. Alabama ex rel. Patterson, 857 U.S. 449,460 (1958)).

${ }^{132}$ Id. at 786-87 n.7. 
and Illinois Board of Elections to support its use of a due process analysis. Finally, the Court cited Williams and Lubin for the proposition that the early filing deadline infringed individuals' right to associate for the advancement of political beliefs and the right of voters to effectively cast their votes. ${ }^{183}$ Consequently, the Court inexplicably redefined its analysis of candidate eligibility requirements in such a way as to infringe upon the substantive due process rights of voters.

Next, the Court announced a three-part balancing test with which to analyze state election laws that infringe individual rights but that nonetheless further legitimate state interests. Justice Stevens asserted that a court must:

1) first consider the character and magnitude of the asserted injury to the rights protected by the First and Fourteenth Amendments that the plaintiff seeks to vindicate. 2) It then must identify and evaluate the precise interests put forward by the State as justifications for the burden imposed by its rule. 3) In passing judgement, the Court must not only determine the legitimacy and strength of each of those interests, it also must consider the extent to which those interests make it necessary to burden the plaintiff's rights. Only after weighing all these factors is the reviewing court in a position to decide whether the challenged provision is unconstitutional. ${ }^{194}$

Incredibly, the Court cited Williams, Bullock, American Party and Ilinois State Board of Elections as support for this balancing test. ${ }^{135}$ After employing the three prongs of the test, the Court then determined that the "'extent and nature' of the burdens ... placed on the voters' freedom of choice and freedom of association . . . unquestionably outweigh [ed] the State's minimal interest in" enacting the statute. $^{136}$

Additionally, the Court in Anderson asserted that burdens on "small political parties or on independent candidates impinge[], by

135 See id. at 787.

134 Id. at 789 (numbering added for clarity).

195 See supra Part III.A (illustrating that the Court unquestionably employed varying degrees of scrutiny in each of these cases).

${ }^{136}$ Anderson, 460 U.S. at 806 . While the Court in Anderson ultimately found the state's interest insufficient to justify the legislation, commentators have noted that the Anderson balancing approach in the abstract may provide a greater degree of constitutional latitude than a heightened scrutiny equal protection analysis because the balancing approach affords greater weight to state interests. See Porto, supra note 14 , at 302 . 
[their] very nature," on First Amendment rights. ${ }^{137}$ The Court specifically alluded to its oft-cited discussion of discrete and insular minorities in footnote 4 of United States $v$. Carolene Products Co., ${ }^{138}$ stating that "because the interests of minor parties and independent candidates are not well represented in state legislatures, the risk that the First Amendment rights of those groups will be ignored in legislative decisionmaking may warrant more careful judicial scrutiny." 39 Recalling that the Court utilized this rationale to justify the employment of strict scrutiny in the context of "suspect classes," it becomes clear that at the same time the Court in Anderson announced a balancing test, it also implied that strict scrutiny may be the appropriate mechanism by which to analyze ballot access restrictions.

\section{A Balancing Test with Ambiguity: Munro v. Socialist Workers Party}

In 1986, the Court decided Munro v. Socialist Workers Party, ${ }^{140}$ its first ballot access case since the development of the Anderson balancing test. While not explicitly announcing the employment of the balancing test, the Court implied its continued adherence to a substantive due process analysis by stating that "the burdens imposed on appellees' First Amendment rights ... are [not] too severe to be justified by the State's interest in restricting access to the general ballot."141 Additionally, because the Court did not discuss potential equal protection violations, it is reasonable to presume that the Court maintained a preference for the Anderson approach. Nevertheless, the opinion in Munro is not without ambiguity. Specifically, the Court chose to compare the analysis of the state statutes and individual rights infringed in Munro with the analyses in Jenness,

${ }^{137}$ Anderson, 460 U.S. at 793-94.

138 United States v. Carolene Products Co., 304 U.S. 144, 152 n.4. (1938).

${ }^{139}$ Anderson, 460 U.S. at 793 n.16.

140479 U.S. 189 (1986). In Munro, the Socialist Workers Party, its nominee, and two voters challenged a Washington State statute that required that a minor-party candidate for a partisan office receive at least one percent of all votes cast for that office in the state's primary election in order to be placed on the ballot for the general election. See id. at 191-93 (citing WASH. REV. CODE $\$ 29.18 .110$ (1985)). The party's nominee received 596 votes of the 681,690 votes cast in the primary. See id. at 192 n.9. As this constituted $0.09 \%$ of the total votes cast, the nominee was denied a place on the general ballot. See id. at 192.

${ }^{141}$ Id. at 196. 
American Party, and Storer. ${ }^{142}$ Further, while the Court in Munro implicitly appeared to rely on the Anderson test, it alluded with equivalent precedential effect to American Party and Jenness through its references to the states' "compelling" and "important" interests in the latter cases. ${ }^{148}$ Additional ambiguity in Munro stems from Justice White's assertion that a state was not required to demonstrate that an election scheme, which demanded a showing of voter support prior to granting access, was a response to any distinct historical phenomenon. Apparently disregarding Justice Black's conclusion in Williams that no merely "theoretically imaginable" danger could justify infringing the fundamental rights of association and effective voting, ${ }^{144}$ Justice White stated that " $[w]$ e have never required a State to make a particularized showing of the existence of voter confusion, ballot overcrowding, or the presence of frivolous candidacies prior to the imposition of reasonable restrictions on ballot access."145 Thus, in seeking to avoid battles concerning evidentiary sufficiency, the Court in Munro announced the constitutionality of proactive state legislation in the area of ballot access restrictions.

Finally, citing Lubin, the Court concluded that "Washington simply has not substantially burdened the 'availability of political opportunity."'146 However, as the ballot restriction in Lubin concerned a filing fee, the Court's examination in that case was doctrinally a pure equal protection analysis ${ }^{147}$ and therefore not necessarily analogous to the reasoning required by the facts of Munro.

${ }^{142}$ See id. at 198-99.

${ }^{145}$ See id. at 193-94.

144 Williams v. Rhodes, 393 U.S. 23, 33 (1968) (citing United Mine Workers v. Illinois State Bar Ass'n, 389 U.S. 217, 224 (1967)).

${ }^{145}$ Munro, 479 U.S. at 19495.

${ }^{146} I d$. at 199 (quoting Lubin v. Parish, 415 U.S. 709, 716 (1974)).

147 See supra text accompanying notes 109-112. As additional evidence of the Court's equal protection analysis in Lubin, note the Court's quotation from Justice Stewart's concurrence in San Antonio Independent School District v. Rodriguez, 411 U.S. 1, 59 n.2 (1973) (Stewart, J., concurring), that "[i] t has been established . . . that the Equal Protection Clause confers the substantive right to participate on an equal basis with other qualified voters whenever the State has adopted an electoral process for determining who will represent any segment of the State's population." Lubin, 415 U.S. at 713-14. 


\section{A Return to Strict Scrutiny?: Norman v. Reed}

In 1992, the Court once again decided the constitutionality of an Illinois ballot access statute in Norman $v$. Reed. ${ }^{148}$ In his analysis, Justice Souter recognized the long-established constitutional right, derived from the First and Fourteenth Amendments, of citizens to create and develop new political parties. ${ }^{149}$ Essentially abandoning the recently announced Anderson balancing test in favor of an equal protection analysis, Justice Souter observed:

To the degree that a State would thwart this interest by limiting the access of new parties to the ballot, we have called for the demonstration of a corresponding interest sufficiently weighty to justify the limitation ... . and we have accordingly required any severe restriction to be narrowly drawn to advance a state interest of compelling importance. ${ }^{150}$

Remarkably, Justice Souter cited Anderson as the source for this "observation." "151

Applying this standard, the Court concluded that the statute as interpreted was overbroad and found the regulation to "violate [] the First Amendment right of political association." 152 Thus, despite

148502 U.S. 279 (1992). Under Illinois law, organizers of a "new" political party were required to secure the signatures of 25,000 eligible voters in order to run candidates for statewide elections. See id. at 282 (explaining ILL. COMP. STAT. 46/10-2 (West 1989)). Similarly, in order to run a candidate in a "political subdivision" of the state, organizers were required to obtain the signatures of 25,000 eligible voters from the subdivision. See id. Finally, if the subdivision itself was comprised of large separate districts, the party organizers were required to collect 25,000 signatures from each separate district. See id. If a party obtained at least five percent of the vote in any general election, it became an "established" party. See id. at 283. Petitioners were members of the Harold Washington Party [hereinafter HWP] - an "established" party in the city of Chicago-but sought to expand the scope of their political activities to Cook County, which subsumes Chicago. See id. However, because Cook County consists of two distinct districts, the "city district" of Chicago and the "suburban district," the aforementioned law required them to obtain 25,000 signatures in each district. See id. at 284. After the HWP was able to secure 44,000 signatures in the city district, but only 7,800 signatures in the suburban district, the question arose as to the impact of the statutory scheme on the ability of the party to obtain ballot access in the city-wide elections, the suburban-district elections, and the overall county-wide elections. See id. at 284-87.

149 See id. at 288.

${ }^{150}$ Id. at 288-89 (citing Anderson v. Celebrezze, 460 U.S. 780, 789 (1983) and Illinois State Bd. of Elections v. Socialist Workers Party, 440 U.S. 173, 184, 186 (1979)); see also Porto, supra note 14, at 304 (stating that Justice Souter "made it clear that strict scrutiny of laws that restrict ballot access [was] not dead").

${ }^{151}$ See Norman, 502 U.S. at 288-89.

152 Id. at 290. The Court thus reversed the Illinois Supreme Court's holding that petitioners were prohibited from using the HWP name in Cook County because HWP 
having seemingly announced previously that an equal protection analysis would be the appropriate mechanism of constitutional review, Justice Souter undertook solely an examination of a First Amendment violation. By failing to engage in a separate equal protection analysis, Justice Souter apparently employed a substantive due process/Anderson-like inquiry. Compounding this confusion, however, the Court evidently utilized a heightened scrutiny review (which had heretofore been consistent with equal protection challenges), as opposed to a balancing test such as that derived in Anderson. ${ }^{153}$

was already an "established" party in Chicago. See id. at 289-90 (noting that ILL. REv. STAT. ch. 46, para. 10-5 (1989) (currently codified at 10 ILL. COMP. STAT. 5/10-5 (West 1993)) prohibited the use of the name of any "established" party). The Illinois Supreme Court had read the statute "so literally as to bar candidates running in one political subdivision from ever using the name of a political party established only in another." Id. at 289 (emphasis added). Justice Souter reasoned that such a "Draconian construction" would prevent the incremental development of new political parties, as only those parties which possessed the initial resources to conduct activities on a broad scale could ever participate in the electoral process on a statewide basis. Id. The Court observed that simply allowing candidates to obtain formal permission to use the name of an established party would accomplish the state's legitimate interest in avoiding voter confusion and the "denigrat[ion of] party cohesiveness." Id. at 285, 290. The Court noted that this was true of the instant case: Timothy Evans, the only HWP candidate to run in Chicago's most recent municipal election, had authorized petitioners to use the HWP name in Cook County. See id. at 290.

153 Additionally, the Court reversed the Illinois Supreme Court's holding which disqualified HWP from ballot access for failing to satisfy the 25,000 signature per component district requirement. See id. at 291-93. The Court observed that the Illinois law essentially "retain [ed] the constitutional flaw at issue in [Illinois State Board of Elections v.] Socialist Workers Party by effectively" requiring a greater number of signatures to obtain ballot access in political subdivisions than to obtain ballot access in statewide elections. See id. at 293; see also supra Part III.A.5 (discussing in detail the Court's rationale and holding in Illinois State Board of Elections). Recall that prior to Illinois State Board of Elections, Illinois law required a new party to secure 25,000 signatures in order to obtain ballot access for statewide elections, but required a new party to secure signatures of five percent of the eligible voters in order to qualify for elections in political subdivisions. See Norman, 502 U.S. at 292. In a direct response to the outcome of Illinois State Board of Elections, the state capped the five percent requirement at 25,000. See id. In Norman however, the Court noted that because new parties seeking access in political subdivisions were required to obtain 25,000 signatures in each component subdivision, such parties were still obligated to obtain a significantly greater number of signatures (a multiple of 25,000) for political subdivisions than for statewide elections. See id. at 293. Thus the essential constitutional infirmity of Illinois State Board of Elections remained. See supra Part III.A.5. Justice Souter noted that although the state may have had a legitimate interest in ensuring that a new party demonstrated adequate public support throughout the subdivision, the instant statute was unconstitutionally overbroad. See Norman, 502 U.S. at 293. Justice Souter asserted that the state could simply have required a party to show a proper distribution of support while maintaining the aggregate 25,000 signature cap. 


\section{Write-in Ballots: Burdick v. Takushi}

In addition to striking down the Illinois election scheme challenged in Norman in 1992, the Court assessed the constitutionality of Hawaii's prohibition on write-in ballots in Burdick v. Takushi. ${ }^{154}$ Writing for a six-member majority, Justice White announced that not every law that "imposes any burden upon the right to vote must be subject to strict scrutiny."155 Justice White reasoned that the Constitution granted to states the power to prescribe the "Times, Places and Manner of holding Elections for Senators and Representatives," 156 and that as a practical matter, states must engage in a "substantial regulation of elections" to avoid chaos. ${ }^{157}$ Finally, a recognition of the fact that all election laws necessarily "affect[] . . . the individual's right to vote and his right to associate," led Justice White to conclude that "to subject every voting regulation to strict scrutiny and to require that the regulation be narrowly tailored to advance a compelling state interest ... . would tie the hands of States seeking to assure that elections are operated equitably and efficiently."158 Consequently, the Court explicitly employed the "more flexible standard" of Anderson. ${ }^{159}$

Thus, remarkably, the Court utilized a standard of strict scrutiny in Norman and a balancing test in Burdick in the very same year. Justice White explained the Court's analysis as follows: In general, the Court would weigh the character and magnitude of the individual interests asserted against the state objectives. (This is essentially the Anderson balancing test.) The "rigorousness" of this inquiry however, would depend upon the extent to which the challenged statute burdened First and Fourteenth Amendment rights. Regulations that impose "severe" restrictions would have to be "narrowly drawn to advance a state interest of compelling importance" (a standard

See id. at 293-94. The Court noted that the internal inconsistency of the Illinois election scheme also fatally undermined the state's asserted interest in requiring a proportional distribution of public support. See id. at 294. Specifically, Justice Souter observed that such distribution was not required of new parties seeking to gain ballot access in statewide elections, and therefore it "requires elusive logic to demonstrate a serious state interest in demanding such a distribution for new local parties." Id.

${ }^{154} 504$ U.S. 428 (1992) (addressing a Hawaiian citizen's allegation that the state's ban on write-in voting infringed his First Amendment right of expression and association).

${ }^{155} I d$. at 432.

${ }^{156} I d$. at 433 (quoting U.S. CoNST. art. I, § 9, cl. 1).

157 See id. (quoting Storer v. Brown, 415 U.S. 724, 730 (1974)).

${ }^{158} I d$. (citation omitted).

${ }^{159}$ Id. at 434. 
uncannily similar to strict scrutiny), but laws that subject voters to "reasonable, nondiscriminatory restrictions" would generally be held constitutional. ${ }^{160}$ Essentially, the Court created a "balancing test" which was no more than a veiled tiered scrutiny analysis-"severe restrictions" must be "narrowly drawn" to advance a compelling state interest (strict scrutiny); but "reasonable" restrictions are presumptively valid (rational basis). ${ }^{161}$

In Burdick, the Court observed that Hawaii's relatively unfettered access to the primary ballot offered disaffected voters sufficient opportunity to express themselves. ${ }^{162}$ Explicitly applying the first prong of the Anderson balancing test, the Court concluded that the ban on write-in voting imposed only a "limited burden" on voters" rights. ${ }^{163}$ Employing the second prong of the test, the Court accepted as valid the State's "legitimate" interests in "avoid[ing] the possibility of unrestrained factionalism at the general election,"164 "averting divisive sore-loser candidacies,"165 and guarding against "party raiding."166 The Court found these interests sufficient to outweigh the "limited burden" imposed on Hawaii's voters and held the ban on write-in ballots to be constitutional. ${ }^{167}$

${ }^{160} I d$. (citations omitted).

${ }^{161}$ Significantly, the Court cited Bullock v. Carter, 405 U.S. 134, 143 (1972), for the proposition that the mere fact that a state election law tends to limit the field of available candidates "does not of itself compel close scrutiny." Burdick, 504 U.S. at 433-44. The Court's allusions to Bullock are of consequence because the Court in Bullock appeared intimately entrenched in the tiered scrutiny approach to analyzing ballot restrictions and ultimately utilized a standard of heightened scrutiny. See Bullock, 405 U.S. at 147 (requiring a showing of necessity).

162 See Burdick, 504 U.S. at 436-37. Hawaii's election statute provided three mechanisms for obtaining access to the primary ballot: filing a petition containing at least one percent of the State's registered voters; qualifying as an "established party"; and qualifying via a designated nonpartisan ballot. See id. at 43436 .

${ }_{163}$ See id. at 438-39.

${ }^{164}$ Id. at 439 (quoting Munro v. Socialist Workers Party, 479 U.S. 189, 196 (1986)).

$163 \mathrm{Id}$.

${ }^{166}$ Id. (citing Tashjian v. Republican Party, 479 U.S. 208, 219 (1986)). Party raiding is generally defined as "the organized switching of blocs of voters from one party to another in order to manipulate the outcome of the other party's primary election." Id. (citation omitted).

${ }^{167}$ See id. at 440 . Additionally, the Court announced that all future bans on writein voting will be presumptively valid if a state's ballot access laws pass constitutional muster. See id. at $441-42$. 


\section{Candidate Qualifications as Distinct from Procedural Regulations: U.S. Term Limits, Inc. v. Thornton}

Sections A and B analyzed the Supreme Court's treatment of state statutes that indisputably constituted restrictions to ballot access. The Court has also assessed the validity of state actions that, although not formally examined under the rubric of ballot access, nevertheless implicate the Court's ballot access jurisprudence. In U.S. Term Limits, Inc. v. Thornton, ${ }^{168}$ the Court addressed the constitutionality of an amendment to the Arkansas Constitution which precluded persons who had served a certain number of terms in the United States Congress from having their names placed on the ballot for election to Congress. ${ }^{169}$ The Court found that the constitutional qualifications for congressional service are "fixed" by the Constitution and may not be supplemented by Congress or by the states. ${ }^{170}$ Thus, while the amendment was facially crafted as a mere regulation of the "Times, Places and Manner of Holding Elections"171 (and thus a ballot access restriction), the Court held the amendment to be a constitutionally invalid attempt to indirectly add qualifications for congressional candidates. ${ }^{172}$

In disposing of the term limit amendment as an impermissible candidacy qualification, the Court had occasion to distinguish the unalterability of the requirements for service enumerated in the "Qualifications Clauses" from the regulatory powers delegated to the States under the "Elections Clause." "Th3 Court thus observed

163115 S. Ct. 1842 (1995).

169 The respondent challenged Section 3 of Amendment 73 to the Arkansas Constitution which expressly acted to "limit the terms of the elected officials." Id. at 1845 (quoting the preamble to the amendment).

170 See id. at 1852-54. The Court rejected the argument that the states possessed control over qualifications as part of the original powers reserved to them by the Tenth Amendment. In so finding, the Court observed that the power to add qualifications necessarily was a right created by the Constitution and thus could not have preexisted within the States prior to the establishment of the Constitution. See id. at 1854-56. Additionally, even assuming arguendo that the States possessed some original power to add qualifications, the Framers clearly intended that the Constitution be the exclusive source of qualifications for members of Congress and thereby divested the States of any inherent power to add qualifications. See id. at 1856-57.

171 Id. at 1867.

172 See id. at 1866-70 (stating that the amendment was simply an "effort to dress eligibility to stand for Congress in ballot access clothing" while the "sole purpose of [the amendment] was to ... prevent the election of incumbents") (citation omitted).

${ }^{173}$ The Court noted that in addition to the three qualifications set forth in Article I, Section 2, other clauses may also be viewed as containing "qualifications" for the members of Congress. See id. at 1847 n.2. 
that " $[t]$ he Framers intended the Elections Clause to grant States authority to create procedural regulations, not to provide States with license to exclude classes of candidates from federal office." 174

Nevertheless, as previously recognized, there necessarily exists an inescapable tension in the distinction between categorically invalid candidate eligibility qualifications and presumptively constitutional procedural regulations. Despite the inevitably nebulous distinction between the two classifications, the Court's choice in terminology-as is often the case in constitutional doctrine-becomes dispositive. Thus, while the term limits in U.S. Term Limits, Inc. were unquestionably candidacy qualifications, it is not immediately clear that the disaffiliation requirements that the Court upheld in Storer which substantively accomplished the task of excluding certain individuals from the ballot, were "procedural" regulations as opposed to substantive "qualifications."

Perhaps the most plausible distinction between the two lines of jurisprudence lay in the Court's observation that its jurisprudence in the area of the Elections Clause differentiated presumptively constitutional "ballot access restrictions" from "qualifications" that are inherently invalid as follows: The former do not "involve measures that exclude candidates from the ballot without reference to the candidates' [popular] support in the electoral process." 175 However, the Court's discussion in U.S. Term Limits of the Elections Clause as granting solely "procedural" power to the states to regulate elections may indicate the Court's intention to act less deferentially when faced with future challenges to restrictive state ballot access statutes.

${ }^{174} I d$. at 1869. As support for the Court's position that the Elections Clause granted purely procedural power to the States, the Court referred to James Madison, who stated that the Clause granted states the power to determine " $[w]$ hether the electors should vote by ballot or viva voce, should assemble at this place or that place; should be divided into districts or all meet at one place, should all vote for all the representatives; or all in a district vote for a number allotted to the district." Id. (quoting 2 THE RECORDS OF THE FEDERAL CONSTITUTION OF 1787, at 240 (Max Farrand ed., 1911)); see also THE FEDERALIST No. 60, at 871 (Alexander Hamilton) (Clinton Rossiter ed., 1961) (stating that the Elections Clause "would be expressly restricted to the regulation of the times, the places, and the manner of elections").

175 U.S. Term Limits Inc., 115 S. Ct. at 1870. 


\section{SURVEY OF RECENT LOWER COURT DECISIONS: EVIDENCE OF CONFUSION}

Part III served to illustrate the Supreme Court's tortuous jurisprudential history in the area of ballot access restrictions. This Part will examine ballot access challenges reviewed by several lower federal courts in 1995 and 1996. As will become evident, the courts had considerable difficulty in discerning the proper method of analysis suggested by the Supreme Court. The different approaches and standards employed by these courts to assess the constitutional validity of similar state regulations serves as further evidence of the inconsistency endemic to the Supreme Court's analysis.

\section{A. Fourth Circuit: McLaughlin v. North Carolina Board of Elections}

In McLaughlin v. North Carolina Board of Elections, ${ }^{176}$ supporters of the Libertarian Party challenged the constitutionality of three provisions of the North Carolina election scheme. ${ }^{177}$ The Libertarians challenged: 1) a provision mandating voter disaffiliation; 2) a provision that a party "ceased to exist" if it failed to poll ten percent of the vote; and 3 ) a requirement that organizers include a sign on ballot access nominating petitions stating that "the signers of th [e] petition intended to organize a new political party."178

In addressing this constitutional challenge, the Fourth Circuit observed that " $[t]$ he appropriate standard governing constitutional challenges to specific provisions of state election laws begins with the balancing test that the Supreme Court first set forth in Anderson $v$. Celebrezze."179 However, the court interpreted the Supreme Court

17665 F.3d 1215 (4th Cir. 1995), cert. denied, 116 S. Ct. 1320 (1996).

177 See id. at 1218-19. In relevant part, the North Carolina election code provided that a "new party" could qualify for ballot access as a political party if it filed a petition containing a number of signatures totalling "at least two percent of the total number of votes cast in the most recent general election for [g]overnor." Additionally, an "established party" was defined as one whose nominee for governor or president secured at least ten percent of the total votes cast in the previous general election for governor or president. One substantial benefit of securing the status of "established party" was that such parties retained the right to appear on the ballot for state and federal offices in the next general election without satisfying the petition requirement. Notably, when a party failed to poll at least ten percent of the votes cast, it ceased to be a "political party" within the meaning of the North Carolina election law and would be forced to qualify as a "new party" again in the following election. Id. (citing N.C. GEN. STAT. §§ 163-96, -97, -122 (1994) (amended 1996)).

${ }^{178} I d$. at 1220 (emphasis omitted).

179 Id. 
in Burdick as having "modified" the Anderson balancing test, adding the provision that "election laws which place 'severe' burdens upon constitutional rights are subject to strict scrutiny." ${ }^{180}$ The court of appeals illustrated this ambiguity, stating that "[i]n short, election laws are usually, but not always, subject to ad hoc balancing." 181 The Fourth Circuit resolved that a court should undergo a preliminary determination of the extent to which personal rights are impinged by the state classification-if a regulation was deemed to "severely" burden individual rights, then strict scrutiny would properly be applied; otherwise, a balancing test would be appropriate. ${ }^{182}$

Applying this test to the North Carolina ballot access regulations, the court found the restrictions to be "undoubtedly severe." Nevertheless, after engaging in an exhaustive case-by-case comparison with the Supreme Court's ballot access cases, the court of appeals concluded that the provisions passed constitutional muster, evidently finding the regulations to be the most narrowly tailored to meet the state's compelling interest. ${ }^{184}$

The court then assessed the constitutionality of the mandatory language on the nominating petitions, finding initially that the language served no legitimate state interest. ${ }^{185}$ However, the court also found it necessary to employ the Anderson balancing test to determine whether the prescription burdened "protected rights." 186 While the court did not require historical proof that protected rights had in fact been invaded, the court did announce that the violation of protected rights must be "the inevitable consequence" of state actions in order to be held invalid. ${ }^{187}$ As the language could

${ }^{180} I d$.

${ }^{181} I d$. at 1221 .

${ }^{182}$ Id.

183 See id.

${ }^{184}$ See id. at 1221-26. Notably, as support for its analysis, the court cited Anderson for the assertion that the Due Process Clause is offended by violations of the right to associate. See id. at 1221. Additionally, the court noted that the "right to form a party for the advancement of political goals means little if a party can be kept off the election ballot and thus denied an equal opportunity to win votes." Id. (quoting Williams v. Rhodes, 393 U.S. 23, 31 (1968)). Remarkably, the court apparently perceived no inconsistency in employing an equal protection analysis and a due process analysis simultaneously. See $i d$.

185 See id. at 1226.

${ }^{186} \mathrm{Id}$. at 1227.

$187 \mathrm{Id}$. 
reasonably be construed in an innocuous manner, the court concluded that the statute was constitutional. ${ }^{188}$

Finally, the court addressed the mandatory disaffiliation requirement. Applying the Anderson balancing test, the court found that the slight burden to the affected parties' associational rights was overcome by the state's interests in administrative simplicity. ${ }^{189}$

\section{B. Sixth Circuit: Corrigan v. City of Newaygo}

In 1995 the Sixth Circuit also had occasion to examine a ballot access restriction scheme in Corrigan v. City of Newaygo. ${ }^{190}$ In Corrigan petitioners asserted the unconstitutionality of a city ordinance that denied ballot access to individuals who were delinquent on their local taxes or water and sewer fees. ${ }^{191}$ The court first assessed the asserted infringement upon the freedom of association, citing Anderson as an example of the "means-to-an-end form of freedom of association" articulated in the Supreme Court's decision in Roberts $v$. United States Jaycees. ${ }^{192}$ Failing to make any reference to either a balancing test or a tiered scrutiny analysis, the court simply analogized the facts to those present in Anderson and concluded that no associational interest was infringed because the tax ordinance was not directed at candidates with substantive views that lie outside the platforms of existing political parties. ${ }^{193}$ In essence, the court determined that because the tax was not a contentbased form of political discrimination, it was not an impermissible ballot access restriction.

Next, the court analyzed a possible equal protection violation against those who were unable to pay the taxes and were thus barred from ballot access. Noting an "unclear" Supreme Court history in the area of wealth discrimination, the circuit court concluded that an

188 See id.

189 See id. at 1227-29.

19055 F.3d 1211 (6th Cir.), cert. denied, 116 S. Ct. 379 (1995).

191 See id. at 1212-13. In May 1993, the Mayor of the City of Newaygo resigned from office under pressure from several citizen groups. Two men, the petitioners in this case, filed petitions to run for mayor. Three days after the filing deadline had passed, the city clerk notified the individuals that they were ineligible to have their names placed on the ballot due to outstanding financial obligations. One man owed $\$ 372.63$ in property taxes and $\$ 48.67$ in water and sewer charges; the other man owed $\$ 318.33$ to the city in property taxes. The sole remaining candidate on the ballot was the ex-mayor. See id.

192 See id. at 1215 (citing Anderson, 460 U.S. at 780; Roberts v. United States Jaycees, 468 U.S. 609 (1984)).

193 See id. 
equal protection challenge was frivolous because no "protected class" was precluded from seeking office. ${ }^{194}$ Despite one petitioner's claim that the tax genuinely excluded him from the ballot due to his inability to pay, the court concluded that "plaintiffs have asserted no fundamental interest that would entitle them to protection as a suspect class under the Equal Protection Clause." ${ }^{195}$ Remarkably, the court found that "we do not have to decide the proper standard of review because this ordinance does not burden the rights of a class entitled to protection under any standard." 196 Finding that only protected classes are deserving of heightened scrutiny, the court ignored any challenge based on the fundamental right of voting and made no mention of a strict scrutiny analysis. The court determined that the restrictions had a rational basis because the ordinance served the legitimate economic purpose of enforcing the city's tax regime.

Finally, and most notably, the court attempted to address the Anderson balancing test. The court stated:

It is unclear whether this means that there is a ballot access potpourri of interests that potentially includes all of the numerous interests protected by the concepts of freedom of association, equal opportunity and privacy, and that all together they should be listed and weighed to see if there is a combination that violates the Due Process, Equal Protection and Free Speech clauses read together. We have sought to view the matter in this way and do not find any interests we have not taken into account in our separate analyses under "freedom of association" and "Equal Protection."

Thus, in determining the constitutionality of the ballot access regime in Corrigan, the Sixth Circuit undertook several independent equal protection and due process analyses. Only then, in an obvious effort to be respectful of the Supreme Court's jurisprudence, did the court make a symbolic attempt to fulfill the Anderson balancing test. As it stated, the Sixth Circuit certainly remained "unclear" as to the impact of Anderson. The court's reference to a nebulous "potpourri of interests" to be balanced once again illustrates the ambiguity and confusion created by the Supreme Court's decisions. ${ }^{198}$

\footnotetext{
194 See id. at 1216.

${ }^{195} I d$.

196 Id.

${ }^{197} I d$. at 1217.

${ }^{198} \mathrm{Id}$.
} 


\section{Eighth Circuit: Republican Party v. Faulkner County}

In 1995, the Eighth Circuit had occasion to apply the Supreme Court's ballot access doctrine in Republican Party v. Faulkner County. ${ }^{199}$ The Republican Party of Arkansas challenged the constitutionality of an Arkansas statutory scheme that required political parties to "both conduct and pay for primary elections as a condition of access to the general election ballot." 200 In assessing the validity of the various state regulations, the court observed that "[t]he Supreme Court has not spoken with unmistakable clarity on the proper standard of review for challenges to provisions of election codes." 201 The court continued, stating that "[i]n some cases, the [Supreme] Court has articulated and employed a flexible test, calibrating the level of scrutiny to the seriousness of the burden imposed by the challenged law; yet on other occasions it has suggested that all election and voting regulations must be subjected to strict scrutiny."202

The Eighth Circuit concluded that although it was not possible to "resolve the [] apparently inconsistent standards of review," the state regulations in the case before it constituted a "severe" burden on individual liberties, warranting strict scrutiny "even under the more flexible, sliding-scale standard of review articulated in Burdick."203 Finally, the court rejected the four interests asserted by the state, ${ }^{204}$ finding that "Arkansas ... failed to identify any

${ }^{199} 49$ F.3d 1289 (8th Cir. 1995).

${ }^{200} \mathrm{Id}$. at 1291 .

201 Id. at 1296.

${ }^{202}$ Id. The Eighth Circuit in Republican Party discussed the flexible, sliding-scale standard announced in Bullock v. Carter, 405 U.S. 134, 143-44 (1972), and employed in Burdick v. Takushi, 504 U.S. 428, $432-34$ (1992), Tashjian v. Republican Party, 479 U.S. 208, 213-14 (1986), and Anderson, 460 U.S. at 788-89. The court noted that in Burdick, the Supreme Court found strict scrutiny appropriate when state regulations "severely" restricted constitutional freedoms. Republican Party, 49 F.3d at 1297 (citing Burdick, 504 U.S. at 434).

In addition, the court considered Eu v. San Francisco County Democratic Central Committee, 489 U.S. 214, 222-33 (1989), for that case's finding that laws imposing "any appreciable burden on rights of association, expression and voting demand[] strict scrutiny." Republican Party, 49 F.3d at 1297.

In examining the Supreme Court's ballot access jurisprudence, the Eighth Circuit also noted that " $[\mathrm{t}] \mathrm{h}$ e precise standards of review [that the Supreme Court employed] in the earliest election code cases cannot so readily be classified." Id. at 1297 n.3.

${ }^{203}$ Republican Party, 49 F.3d at 1297.

${ }^{204}$ Arkansas advanced the following state interests: "1) protecting and preserving the integrity of the nominating process, 2) minimizing voter confusion, 3) protecting the public from frivolous or fraudulent candidates, and 4) maximizing the probability that the winning candidate will have received a majority of the popular vote." Id. at 
compelling state interest which necessitates the imposition of such heavy burdens on the associational rights of parties and voters," and concluded that the state requirements were unconstitutional. ${ }^{205}$

\section{Northern District of Georgia: Duke v. Cleland}

In 1995, the District Court for the Northern District of Georgia assessed the constitutionality of a Georgia statute that permitted the State Candidate Selection Committee to delete any candidate's name from the ballot if all Committee members of the same political party voted to drop the name. ${ }^{206}$ In Duke, all three Republican members of the Committee voted to drop David Duke's name from the presidential ballot and subsequently denied Duke's appeal for reconsideration. ${ }^{207}$

Ruling on counter motions for summary judgment, the district court observed that its task, as defined by the Eleventh Circuit, was to determine "with particularity the interests purportedly advanced by [the Georgia statute and to] weigh them against the purported burden upon the plaintiffs' constitutional rights, then apply the proper level of scrutiny pursuant to the teachings of Anderson and Burdick." ${ }^{208}$ Nevertheless, the district court's analysis consisted of a methodical determination and examination of the respective interests of the state and the individuals, followed by a strict scrutiny review "for the sake of caution."209

1299. While the court recognized these interests as "legitimate," it found that Arkansas "fail[ed] to indicate how any of [the interests] necessitate[d] the burdens imposed." Id.

${ }^{205} \mathrm{Id}$. at 1301.

${ }^{206}$ See Duke v. Cleland, 884 F. Supp. 511 (N.D. Ga. 1995), aff'd sub nom. Duke v. Massey, 87 F.3d 1226 (11th Cir. 1996).

${ }^{207}$ In Duke v. Cleland, 954 F.2d 1526 (11th Cir. 1992), the Eleventh Circuit affirmed the district court's denial of a request for an injunction and temporary restraining order that, if granted, would have prohibited the printing of ballots unless Duke's name was listed. That decision merely determined, however, that the Committee acted constitutionally in excluding Duke's name from the ballot, because the Republican Party's right to define its membership outweighed both Duke's right to associate with the party and citizens' rights to vote for Duke in the Republican primary. See id. at 1530-33.

Duke and his supporters then amended their complaint to challenge the Georgia statute itself, alleging that the statute violated their First and Fourteenth Amendment rights. The district court dismissed, finding a lack of state action. The Eleventh Circuit in Duke v. Cleland, 5 F.3d 1399 (11th Cir. 1993), held that the Committee's action did constitute state action and remanded the case to the district court. See id. at 1405-06. The present case concerns this issue.

${ }^{203}$ Duke, 884 F. Supp. at 514 (quoting Duke, 5 F.3d at 1405-06).

${ }^{209} \mathrm{Id}$. at 517. 
The court found that the statute furthered the state's interest in enhancing the expediency and efficiency of the electoral process. The court also determined that the state's interest in "maintaining and facilitating the Republican Party's ability to control its identity" was "legitimate and compelling."210 The court then undertook separate analyses of the rights of voters and Duke's right to be a candidate. The court rejected plaintiffs' assertion that voters maintain an absolute right to vote for the candidate of their choice and dismissed plaintiffs' claim of a right to vote for Duke as a Republican (as opposed to voting for Duke as an independent). Finally, the court found that Duke's right of association was not infringed by the exclusion of his name from the ballot. ${ }^{211}$

The decision in Duke is perhaps most notable for the court's rationale and its use of the strict scrutiny test to determine the constitutionality of the Georgia statute. Befuddled at the current state of Supreme Court jurisprudence on the issue, the Northern District of Georgia stated that "for the sake of caution, the court will apply the strict scrutiny test to determine whether the statute was 'narrowly tailored to advance a compelling state interest."'212 The delicate balance between advancing state interests in regulating the ballot and protecting "our most precious freedoms" of association and voting certainly deserves a more precise method of analysis than application of a particular standard for no other reason than "for the sake of caution."

$210 \mathrm{Id}$. at $515-16$.

211 Id. at 516. The court regarded the Eleventh Gircuit's opinion in Duke $v$. Cleland, 954 F.2d 1526 (11th Cir. 1992), as determining that Duke's right of association was "not infringed by the decision of the" Committee. Duke, 884 F. Supp. at 516. However, a more plausible interpretation may be that the Eleventh Circuit merely found that the right of the Republican Party to define its membership outweighed Duke's right of association. Under this interpretation, the Eleventh Circuit's opinion implicitly recognized the existence of Duke's right of association, without determining the expansiveness of the right.

${ }^{212}$ Duke, 884 F. Supp. at 517 (quoting Burdick v. Takushi, 504 U.S. 428, 433 (1992)). Ultimately, the Court in Duke upheld the statute, finding that it was narrowly tailored to advance the state's compelling interest in allowing parties to choose their candidates. See id. at 517-18.

${ }^{213}$ See Williams v. Rhodes, 393 U.S. 23, 30 (1968) (observing the "precious rights" of association and voting implicated by ballot access restrictions). 


\section{E. Southern District of New York: Gelb v. Board of Elections}

In Gelb v. Board of Elections, ${ }^{214}$ the District Court for the Southern District of New York addressed the constitutionality of actions and omissions of the New York Board of Elections during the 1993 primary and general election for the office of Bronx Borough President. ${ }^{215}$ Remarkably, in evaluating the defendant's motion to dismiss, the district court observed that "the Supreme Court has rejected the application of strict scrutiny to every voting rights case. Instead, a flexible standard of review is employed." 216

The district court then analogized the plaintiff's complaint to the constitutional challenges asserted in Williams $v$. Rhodes, and held that "[b]y allegedly engaging in acts and omissions designed to undermine write-in candidacies, the effect of defendants' actions was to bolster the candidacies of people nominated by the established parties. $^{\text {217 }}$ The district court apparently interpreted all Supreme Court ballot access cases as employing the Anderson balancing test, despite the Supreme Court's use of a more stringent standard in Williams and Illinois State Board of Elections. ${ }^{218}$ Further, the District Court in Gelb was evidently so confident that strict scrutiny was inappropriate in the area of ballot access that it cavalierly chose to analogize the facts of Gelb to Williams, instead of another Supreme Court case that more clearly utilized the flexible standard, such as Anderson or Munro.

\section{F. Eastern District of New York: Rockefeller v. Powers}

In Rockefeller v. Powers, ${ }^{219}$ the Eastern District of New York granted a preliminary injunction to registered Republican voters who asserted that New York state election laws and Republican Party rules regulating the nominating petition process violated the First Amendment and the Equal Protection Clause of the Fourteenth Amendment. ${ }^{220}$ The district court interpreted the Supreme Court's juris-

214888 F. Supp. 509 (S.D.N.Y. 1995).

${ }^{215}$ See id. The plaintiff did not question the constitutionality of the statutory scheme itself, but rather asserted that the actions of the Board of Elections deprived him and others of their First, Fourth, and Fourteenth Amendment rights. See id. at 511-13.

${ }^{216}$ Id. at 515 (citation omitted).

217 Id. at 517.

218 See supra Part III.

219909 F. Supp. 863 (E.D.N.Y. 1995), rev'd, 74 F.3d 1367 (2d Cir. 1995), cert. denied, 116 S. Ct. 1703, and cert. denied, 116 S. Ct. 1704 (1996).

${ }^{220}$ See id. at 872 . As applied to the Republican Party, the New York law requires 
prudence as a formulation of "two distinct lines of analysis" representing due process and equal protection challenges. ${ }^{221}$ Thus, the Eastern District of New York asserted that "[r] egulations that impose burdens that are generally applicable to all voters are usually treated deferentially under a balancing test." ${ }^{222}$ The court stated that "[i]n contrast, the cases dealing with requirements that treat similarly situated voters differently have imposed a more probing, less deferential level of scrutiny under the Equal Protection Clause."223 Consequently, the court found that " $[w]$ here the difference is de minimis, only a rational basis is required. Where it 'impairs the voters' ability to express their political preferences,' heightened scrutiny is required."224

The district court in Rockefeller declared that "[ $t]$ he leading case analyzing ballot access signature requirements under the Equal Protection Clause is Ilinois State Board of Elections." 225 The court reasoned that "[i]n the context of [primary elections], candidates who are independent of the party organization are . . . analogous to third parties at a general election" and concluded that the different burdens required by the New York scheme "raise exactly the same question ... here as in [Illinois State Board of Elections v.] Socialist Workers Party." 226 Thus, the district court found that "[u]nder any test-strict scrutiny, balancing of interests, or rational basis-the rules at issue here, which have the practical effect of limiting voters' choices and curtailing political expression, cannot be sustained."227

Interpreting the lower court to have applied strict scrutiny to strike down the state's registration requirement, the Second Circuit determined that "the district court was incorrect to conclude, as it

that delegate candidates secure signatures totaling the lesser of five percent or 1250 enrolled party members in their districts in order to have their names placed on the primary ballot. Due to disparities in population and the distribution of Republicans in the various districts, the requirement imposes on candidates substantially different burdens corresponding with different districts. See id. at 864 (citing Act of Aug. 8, 1995 N.Y. Laws 586). The court observed that only six congressional districts contained fewer than 25,000 Republicans and thus forced candidates to comply with the full five percent requirement; however in 20 of the districts, the 1250 signature cap resulted in an operative signature requirement of $1.54 \%$ or less. See id. at $864-65$.

${ }^{221} I d$. at 865 .

$222 I d$.

${ }^{223} I d$. at 866.

${ }^{224}$ Id. (quoting Illinois Bd. of Elections v. Socialist Workers Party, 440 U.S. 173, $184(1979))$.

${ }_{225} I d$.

${ }^{226} I d$. at $868-69$.

227 Id. at 869. 
apparently did, that the broad language of [Illinois State Board of Elections v.] Socialist Workers Party automatically requires strict scrutiny for ballot access measures that result in any sort of disparate treatment." ${ }^{228}$ The court of appeals apparently found that the Supreme Court had made ballot access jurisprudence "clear," stating that:

The critical question ... is "the extent to which a challenged regulation burdens First and Fourteenth Amendment [voting] rights."...

... [I]f ballot access rules affected two groups of people differently, such that different "appreciable" (or "significant," or "substantial," or "severe") burdens were imposed on the fundamental right to vote of the two groups, then strict scrutiny would apply. ${ }^{229}$

Imposing this test, the Second Circuit found that "the evidence [did] not indicate a causal connection between the challenged regulation and the alleged injury."230 Concluding that plaintiff's right to vote was "certainly not 'preclu [ded]' . . . [nor] significantly burden [ed]," the court applied a "rational basis analysis." ${ }^{231}$ Not surprisingly, the court then determined several legitimate governmental interests to which the registration requirements were rationally related and summarily reversed the district court and vacated the injunction. ${ }^{232}$

${ }^{228}$ Rockefeller v. Powers, 74 F.3d 1367, 1377 (2d Cir. 1995), cert. denied, 116 S. Ct. 1703, and cert. denied, 116 S. C. 1704 (1996).

${ }^{229} \mathrm{Id}$. at $1378 \mathrm{n} .16$ (quoting Burdick v. Takushi, 504 U.S. 428, 434 (1992)) (first alteration in original).

${ }^{230} \mathrm{Id}$. at 1379. The court found: 1) that no correlation existed between the districts with less than two candidates on the ballot and the number of registered Republicans in those districts; 2) that the plaintiff's argument was flawed because it relied on the choice of presidential candidates available to primary voters in different districts, while in reality, each district voted for delegates to the national conventionnot for presidential candidates; 3) that registered Republicans in districts with fewer registered Republicans actually received a "substantial benefit" because of the relative power of their votes. Id. at 1379-81.

231 Id. at 1382 (first alteration in original).

${ }^{232}$ See id. at 1382-83 (identifying the state's interest in weeding out candidates with insufficient support and its countervailing interest in protecting potential candidates in districts where an across-the-board percentage requirement would be unduly burdensome). 


\section{G. Summary of Lower Court Decisions}

Illustrating the Supreme Court's inconsistent treatment of challenges to state ballot access restrictions and the subsequent lack of clear precedential effect to federal judges and state legislatures, Part IV presented recent decisions of various lower federal courts. In McLaughlin, the Fourth Circuit determined that the appropriate standard to examine ballot access restrictions was a "modified" Anderson balancing test. ${ }^{233}$ When presented with a similar state regulation in Corrigan, the Sixth Circuit simply analogized the facts of Anderson to the instant fact pattern and cursorily noted the "unclear" standard of review suggested by the Supreme Court. ${ }^{234}$ The Eighth Circuit remained unable to "resolve [the] . . . inconsistent standards of review," noting that "[i]n some cases, the [Supreme] Court has articulated and employed a flexible test . . . yet on other occasions it has suggested that all election and voting regulations must be subjected to strict scrutiny."285 Similarly uncertain as to the proper methodology or standard, the Northern District of Georgia utilized a strict scrutiny standard "for the sake of caution" in Duke v. Cleland. ${ }^{236}$ On the other hand, the Southern District of New York confidently asserted that the Supreme Court had "rejected the application of strict scrutiny to every voting rights case" and instead employed a "flexible standard" in Gelb $\%$. Board of Elections. ${ }^{237}$ The Eastern District of New York observed in Rockefeller $v$. Powers that the Supreme Court cases constituted two distinct lines of analysis. ${ }^{238}$ Thus, the Southern District of New York resolved that for substantive due process challenges, it is proper to employ a balancing test; however, for equal protection challenges, a "more probing, less deferential level of scrutiny" is appropriate. ${ }^{239}$ The Second Circuit disagreed and in overruling the Southern District, declared that the level of scrutiny to be applied depended upon the

239 See supra Part IV.A.

${ }^{234}$ See supra Part TV.B.

${ }^{235}$ Republican Party v. Faulkner County, 49 F.3d 1289, 1296-97 (8th Cir. 1995); see also supra Part IV.C.

236884 F. Supp. 511,517 (N.D. Ga. 1995); see also supra Part IV.D. IV.E.

237888 F. Supp. 509, 515 (S.D.N.Y. 1995) (citation omitted); see also supra Part

${ }^{2 s 8}$ See Rockefeller v. Powers, 909 F. Supp. 863 (E.D.N.Y. 1995), rev'd, 74 F.3d 1367 (2d Cir. 1995), cert. denied, 116 S. Ct. 1703, and cert. denied, 116 S. Ct. 1704 (1996); see also supra Part IV.F.

${ }^{259}$ Id. at 865-66. 
"extent to which a challenged regulation burden[ed]" protected voting rights. ${ }^{240}$

Within one year, seven different federal courts undertook seven vastly different methods of analysis in assessing substantially similar state regulations. This summary makes abundantly clear that perhaps the only element of this area of law on which the various courts concur is the lack of clarity supplied by the Supreme Court.

\section{ANALYSIS}

Assuming arguendo that the Court will continue to analyze alleged violations of equal protection and substantive due process within the framework of tiered scrutiny, ballot access restrictions should be examined through the lens of strict scrutiny. Access restrictions necessarily implicate the freedom of political association and the right to vote, both of which have been accepted by the Court to be fundamental in character. ${ }^{241}$ Because strict scrutiny was created to be the mechanism with which to examine state regulations which burden fundamental rights, it is logically inconsistent and intuitively imprudent for the Court to deny this heightened scrutiny to two of our "most precious freedoms." 242 The Court should employ a method of analysis that recognizes the fundamental nature of the individual rights infringed and enables states to effectively regulate the process of elections. Utilizing a genuine and nonconclusory tiered scrutiny analysis that accords appropriate weight to the states' objectives in regulating the ballot and the individual constitutional interests infringed will accomplish these objectives. ${ }^{243}$

${ }^{240}$ Rockefeller v. Powers, 74 F.3d 1367, 1377 (2d Cir. 1995), cert. denied, 116 S. Ct. 1703, and cert denied, 116 S. Ct. 1704 (1996).

${ }^{241}$ See supra notes 66-68 and accompanying text; but see Gardner, supra note 3 (manuscript at 3, on file with the University of Pennsylvania Law Review) (observing that "[i]n a contradiction unparalleled in constitutional law, the Court has said both that the Constitution 'undeniably' protects the right to vote in state and federal elections-and that the right to vote 'is not a constitutionally protected right'").

242 Williams v. Rhodes, 393 U.S. 23, 30 (1968).

243 The Court's reasoning in many of the ballot access cases implies that use of a strict scrutiny standard must result in an invalidation of the state law. For example, Justice White's observation in Burdick $v$. Takushi that all election laws must necessarily "affect[] . . . the individual's right to vote and his right to associate," led him to the conclusion that "to subject every voting regulation to strict scrutiny and to require that the regulation be narrowly tailored to advance a compelling state interest . . . would tie the hands of States seeking to assure that elections are operated equitably and efficiently." 504 U.S. 428, 433 (1992) (quoting Anderson v. Celebrezze, 460 U.S. 780, 788 (1983)). Consequently, the Court in Burdick employed a "more flexible standard" than strict scrutiny. Id. at 434. However, see infra notes 265-71 and accompanying 


\section{A. Proposed Test}

As Part IV illustrated, lower courts are confused as to the appropriate method of evaluating the constitutionality of state election schemes. The Supreme Court should announce a clear and coherent standard that will enable courts to analyze ballot access restrictions consistently and will provide states with a higher degree of confidence in the validity of their election laws. The history of the Court's analysis indicates two distinct areas of confusion that must be resolved. First, the Court should distinguish instances where an equal protection analysis is appropriate from instances where a due process analysis is appropriate. Because this is a modest doctrinal matter that has been previously reconciled, the Court should simply apply the appropriate standards consistently. Second, the Court should determine whether a balancing test or a tiered scrutiny analysis $^{244}$ is appropriate to analyzing ballot access restrictions. While a balancing test may appear to provide courts with greater leeway to evaluate competing interests, courts may also capture this benefit in a system of tiered scrutiny which accurately measures states' and individuals' respective interests. Furthermore, a system of tiered scrutiny provides a more coherent and administrable standard to lower courts and tends to afford a more appropriate level of deference to state legislative enactments. Finally, because the Court continues to use a tiered scrutiny analysis in other equal protection and due process challenges, the Court should employ such a method when evaluating ballot access restrictions.

\section{Due Process v. Equal Protection}

Prior to its decision in Anderson v. Celebrezze, ${ }^{245}$ the Supreme Court analyzed all ballot access restrictions under the rubric of equal protection analysis. ${ }^{246}$ However, as it noted cavalierly in a footnote, the Anderson Court did not "engage in a separate Equal Protection Clause analysis," but instead utilized a substantive due process analy-

text for the argument that use of strict scrutiny will not necessarily be inconsistent with a finding that state election schemes are constitutionally valid.

244 The Court traditionally employed a "two-tiered" model of review. A state statute was either subjected to "rational basis" or "strict scrutiny." Subsequently, the Court added a "middle-level of scrutiny." See infra notes 257-58 and accompanying text (evidencing the Court's continued adherence to a tiered system).

245460 U.S. 780 (1983).

${ }^{246}$ See supra Part III.A. 
sis. ${ }^{247}$ This subsequently left observers and lower courts with considerable doubt as to the appropriate method of analysis. Nevertheless, despite lower courts' understandable confusion regarding whether substantive due process or equal protection is the correct form of analysis in the area of ballot access, as a general doctrinal matter, the appropriate application of either substantive due process or equal protection is a rather fundamental concept and should not be problematic. As the district court in Rockefeller stated, "[r] egulations that impose burdens that are generally applicable to all voters" must be examined under the Due Process Clause to determine "whether [the regulations] place[] too great a restriction on ballot access, regardless of the burdens imposed [on voters] in other districts."248 Alternatively, "requirements that treat similarly situated voters differently" must be evaluated under the Equal Protection Clause. ${ }^{249}$

While this settles the issue from a theoretical perspective, as a practical matter the Court must still determine whether a state regulation that burdens a minor party or an independent candidate constitutes an equal protection violation or a due process infringement. A due process challenge may be validly asserted whenever constitutional rights are infringed. ${ }^{250}$ Accordingly, in discussing the substantive liberties protected by the Fourteenth Amendment in Planned Parenthood v. Casey, ${ }^{251}$ Justice O'Connor stated that the Due Process Clause "has been understood to ... "bar[] certain government actions regardless of the fairness of the procedures used to implement them.""252 Because ballot access restrictions implicate

247 Anderson, 460 U.S. at $786-87$ n.7.

${ }^{248}$ Rockefeller v. Powers, 909 F. Supp. 863, 865 (E.D.N.Y. 1995), rev'd, 74 F.3d 1367 (2d Cir. 1995), cert. denied, 116 S. Ct. 1703, and cert. denied, 116 S. Ct. 1704 (1996).

${ }^{249} \mathrm{Id}$. at 866. The district court in Rockefeller was, however, careful to note that the Supreme Court often failed to distinguish between these two analytical inquiries. See id. at 865 n.1. Additionally, note Justice Harlan's observation in Shapiro v. Thompson, 394 U.S. 618 (1969):

[When] a classification is based upon the exercise of rights guaranteed against state infringement by the Federal Constitution, then there is no need for any resort to the Equal Protection Clause; in such instances, this Court may properly and straightforwardly invalidate any undue burden upon those rights under the Fourteenth Amendment's Due Process Clause.

Id. at 659 (Harlan, J., dissenting).

${ }^{250}$ See Shapiro, 394 U.S. at 661-62 (Harlan, J., dissenting).

251505 U.S. 833 (1992). See also Shapiro, 394 U.S. at 661-62 (Harlan, J., dissenting) (stating that " [w] hen the right affected is one assured by the Federal Constitution, any infringement can be dealt with under the Due Process Clause").

${ }^{232}$ Casey, 505 U.S. at 846 (quoting Daniels v. Williams, 474 U.S. 327, 331 (1986)). 
the fundamental rights to vote and to associate, courts may reasonably analyze challenges to state regulations under the aegis of substantive due process.

Alternatively, as Professor Tribe has observed, "equality can be denied when government classifies so as to distinguish . . . between persons who should be regarded as similarly situated in terms of the relevant equal protection principles." ${ }^{253}$ Thus, parties may also appropriately assert ballot access challenges under the Equal Protection Clause. The appropriate inquiries under such a test would be whether supporters of minority parties and independent candidates are "similarly situated" with supporters of majority parties and whether they are treated "differently" in a manner that the Constitution is bound to respect. ${ }^{254}$

Unquestionably, the applicability of the Due Process Clause or the Equal Protection Clause to determine the constitutionality of a state ballot access restriction will, to a certain extent, depend upon the particularities of the state regulation. Nevertheless, while the burdens imposed by different state ballot access laws are distinct, the laws themselves will undoubtedly burden the rights of voters who support minority parties and independent candidates, and in this respect will be equivalent. Therefore, the Supreme Court may effectively and conclusively determine this issue by declaring either

233 TRIBE, supra note 2, at 1438.

${ }^{254}$ Recall that the Court has refused to acknowledge a distinct fundamental right of candidacy. See Bullock v. Carter, 405 U.S. 134, 142-43 (1972); TRIBE, supra note 2, at 1098.

Clearly, supporters of a minority party or an independent candidate are being treated "differently," in the colloquial sense, by a state election law that requires such political entities to submit to different standards than established or majority parties. In several important respects, however, supporters of such parties are not treated differently. First, the particular parties themselves are not subject to adverse treatment in the sense that the regulations apply to all parties. The current minority parties are simply those that happen to fall into the category of "minority" party at one specific point in time. These parties, however, may soon become "majority" or "established" parties and thus will no longer be subject to the "different" treatment; similarly, the current "majority" parties may fall out of favor and become subject to the "different" treatment. Second, the supporters of minority parties are not treated differently in the respect that state statutes are facially neutral and do not discriminate on the basis of specific political beliefs. Thus, the voters are not treated differently because of their "radical" beliefs, but rather because they are relatively unsupported in their beliefs to such a degree that ballot access may be unwarranted. Professor Tribe thus states that not every "political outcome which operates to an individual's disadvantage should be deemed to deny treatment as an equal, but only to single out for special scrutiny and probable invalidation those disadvantageous political judgements which seem likely to reflect a preference based on prejudice." Id. at 1438 . 
that such statutory schemes are to be dealt with in a due process context or in an equal protection context. ${ }^{255}$ In short, regardless of which approach the Court adopts, it must do so consistently. ${ }^{256}$

\section{Tiered Scrutiny}

As many recent decisions evidence, the Supreme Court has maintained its use of a tiered scrutiny approach to analyze allegations of substantive due process and equal protection violations. ${ }^{257}$

${ }^{255}$ It should be clear, however, that analysis under the Due Process Clause is distinct from analysis under the Equal Protection Clause and in certain instances only one constitutional protection is available. See supra notes $248-49$ and accompanying text (explaining the applicability of due process and equal protection challenges to distinct infringements of constitutional liberties as articulated by the Eastern District of New York in Rockefeller v. Powers, 909 F. Supp. 863 (E.D.N.Y. 1995), rev'd, 74 F.3d 1367 (2d Cir. 1995), cert. denied, 116 S. Ct. 1703, and cert. denied, 116 S. Ct. 1704 (1996).

${ }^{236}$ Note however that the applicability of the two constitutional protections is not necessarily mutually exclusive. See Rockefeller, 909 F. Supp. at 866 (illustrating that "a restriction that would withstand a Due Process/First Amendment challenge, could nonetheless fail to survive a challenge made under the Equal Protection Clause, if not applied uniformly").

For a lengthy discussion of the importance of consistency, see Justice O'Connor's opinion in Casey, 505 U.S. at 854 (stating that "the very concept of the rule of law underlying our own Constitution requires such continuity over time").

257 See Miller v. Johnson, 115 S. Ct. 2475 (1995) (applying strict scrutiny and concluding that Georgia's legislative redistricting plan violated equal protection); Florida Bar v. Went for It, Inc., 115 S. Ct. 2371 (1995) (holding that although lawyers' solicitation constituted commercial speech, the Florida Bar's 30-day ban on targeted direct mail solicitation withstood intermediate scrutiny); Adarand Constructors, Inc. v. Pena, 115 S. Ct. 2097 (1995) (holding that all race-based classifications, whether state or federal, benign or malign, must be subjected to strict scrutiny, and remanding challenge of federal highway program designed to encourage participation of disadvantaged classes in highway construction contracts); Turner Broad. Sys., Inc. v. FCC, 512 U.S. 622 (1994) (holding that "must-carry" provisions of Cable Television Consumer Protection and Competition Act of 1992 were subject to intermediate level of scrutiny applicable to content-neutral restrictions on speech); Smith v. Shalala, 5 F.3d 235, 239 (7th Cir. 1993) (holding that "[b]ecause [a] classification based on marital status does not involve a suspect class ... [ [the Court] must examine it under the rational basis test"), cert. denied, 510 U.S. 198 (1994).

While the death of Lochner v. New York, 198 U.S. 45 (1905) (holding constitutionally invalid a New York law that limited the working hours of bakery employees as an abridgement of the "liberty of contract"), brought about by the decisions in Nebbia v. New York, 291 U.S. 502 (1934) (sustaining a New York regulatory scheme for fixing milk prices) and West Coast Hotel v. Parrish, 300 U.S. 379 (1937) (upholding state minimum wage laws for women) signaled the demise of substantive due process in the economic realm, it is clear that the Court continues to view the Due Process Clause of the Fourteenth Amendment as a restraint on a state's power to infringe personal liberties protected by the first 10 amendments. See Casey, 505 U.S. at 848 (stating that "[n]either the Bill of Rights nor the specific practices of States at the 
Therefore, assuming that the Court will continue to employ this methodology in other areas of constitutional jurisprudence, it is logically consistent and intuitively reasonable to assert that the Court should employ such a method in the area of ballot access jurisprudence as well. ${ }^{258}$

time of the adoption of the Fourteenth Amendment marks the outer limits of the substantive sphere of liberty which the Fourteenth Amendment protects").

${ }^{258}$ But see San Antonio Indep. Sch. Dist. v. Rodriguez, 411 U.S. 1, 98-99 (1973) (Marshall, J., dissenting) (rejecting the Court's usage of "neat categories which dictate the appropriate standard of review" in favor of a "reasoned approach").

Discussion concerning the use of a balancing test instead of a tiered-scrutiny system seems to result from the often conclusory aspect of the latter method. See supra notes 243-44 and accompanying text (noting that the conclusory nature of the Court's reasoning in many of the ballot access cases led to the creation of a more flexible standard). Justice Marshall also expressed frustration with tiered scrutiny in his dissent in Dandridge v. Williams:

In my view, equal protection analysis of this case is not appreciably advanced by the a priori definition of a 'right,' fundamental [and thus invoking the "compelling state interest" test] or otherwise. Rather, concentration must be placed upon the character of the classification in question, the relative importance to individuals in the class discriminated against of the governmental benefits that they do not receive, and the asserted state interests in support of the classification.

397 U.S. 471, 520-21 (1970) (Marshall, J., dissenting) (citation omitted).

Justice Marshall's attack on the tiered-scrutiny system continued in his dissent in Rodriguex, 411 U.S. at 98-110. Marshall's concerns were twofold: First, in many instances strict scrutiny was "strict in theory but fatal in fact," Adarand v. Pena, 115 S. Ct. 2097, 2100 (1995), thus making the determination of standards dispositive of the larger constitutional question. See Rodriguex, 411 U.S at 98-99 (Marshall, J., disagreeing with the Court's rigid equal protection analysis). Second, strict scrutiny was reserved for "suspect classes" and "fundamental rights." Id. at 99 ("I . . cannot accept . . . that fundamental interests, which call for strict scrutiny of the challenged classification, encompass only established rights which we are somehow bound to recognize from the text of the Constitution itself."). But, as the Court's internal debates concerning the validity of substantive due process to protect rights beyond those explicitly enumerated in the text of the Constitution attest, finding a liberty to be "fundamental" in the constitutional sense often has little to do with the societal or immediate importance of the liberty. See id. at 33-34 ("[T] he key to discovering whether education is fundamental is not to be found in comparisons of the relative societal significance of education .... [ [but] [r]ather ... whether there is a right to education explicitly or implicitly guaranteed by the Constitution.").

Thus, the combination of a conclusory system of tiered scrutiny and restrictive access to heightened scrutiny led Justice Marshall to conclude that this regime would lead to anomalous results-state regulations affecting significant and perhaps lifedeterminative rights could be found to affect only "nonfundamental" interests and thus upheld, while state regulations implicating "fundamental" rights but having only a trivial impact on any individual liberties would be struck down. Not surprisingly, Justice Marshall favored a "sliding scale" of scrutiny which would not only balance the state and individual interests, but also would invoke a level of scrutiny relative to the nexus between the specific constitutional guarantee and the individual liberty 
Assuming that the Court should employ a tiered-scrutiny approach to constitutional challenges of ballot access schemes, strict scrutiny is undeniably the appropriate standard by which to protect the "fundamental" rights which laws dealing with the electoral process necessarily implicate. First, even as the Court announced the balancing test in Anderson $v$. Celebrezze, ${ }^{259}$ it conceded that state election codes "inevitably affect[] ... the individual's right to vote and his right to associate with others for political ends." 260 The Court has unambiguously recognized the fundamental character of the right to vote and the right of association. ${ }^{261}$ Because the Court

implicated. See id. at 99.

In light of the Court's more recent jurisprudence, both of Justice Marshall's concerns seem unwarranted. First, the Court has declared and demonstrated that strict scrutiny is not fatal in fact. See Adarand, 115 S. Ct. at 2117 ("[W]e wish to dispel the notion that strict scrutiny is 'strict in theory, but fatal in fact." (citation omitted)); infra note 282 and accompanying text; see also Burns v. Fortson, 410 U.S. 686 (1973) (per curiam) (applying strict scrutiny and accepting state regulations that required a 50-day durational voter residency); Martson v. Lewis, 410 U.S. 679 (1973) (per curiam) (applying heightened scrutiny and upholding 50-day voter residency and registration requirements for non-presidential elections); Korematsu v. United States, 323 U.S. 214 (1944) (applying strict scrutiny and sustaining a military order excluding Americans of Japanese origin from West Coast areas following Pearl Harbor); see generally TRIBE, supra note 2, at 1451-52. Second, ballot access restrictions necessarily implicate the fundamental rights of voting and association, thus eliminating any question as to the appropriateness of strict scrutiny in this context. See supra notes 4849 and accompanying text (discussing the fundamental rights implicated by ballot access restrictions). Consequently, any concerns that a proper measuring of interests and weighing of liberties will not take place under a system of tiered scrutiny are unfounded.

Finally, because the Court has employed a tiered-scrutiny analysis in other areas of equal protection and substantive due process, it is logically consistent and appropriate for the Court to also utilize such a regime in the context of ballot access restrictions. See generally infra notes 269-70 and accompanying text (noting the need for consistency in reviewing laws that infringe upon fundamental rights); supra note 256 and accompanying text (quoting Casey, 505 U.S. at 833, 854, for the proposition that the Court must maintain jurisprudential consistency).

${ }^{259} 460$ U.S. 780 (1983).

${ }^{260}$ Id. at 788.

261 See Williams v. Rhodes, 393 U.S. 23, 30 (1968) ("[T] he right of individuals to associate for the advancement of political beliefs, and the right of qualified voters ... to cast their votes effectively. ... rank among our most precious freedoms."). The Court has also stated that because "suffrage is a fundamental matter in a free and democratic society [and] is preservative of other basic civil and political rights, any alleged infringement . . . must be carefully and meticulously scrutinized." Reynolds v. Sims, 377 U.S. 533, 561-62 (1964) (emphasis added).

Additionally, the Court in Reynolds noted that to "the extent that a citizen's right to vote is debased, he is that much less a citizen." Id. at 567. Similarly, the Court has stated that " $[\mathrm{n}]$ o right is more precious in a free country than that of having a voice in the election of those who make the laws under which, as good citizens, we must 
has consistently applied the strict-scrutiny standard to challenges of laws which infringe fundamental rights, the Court should view all ballot access restrictions through the veil of heightened scrutiny. ${ }^{262}$

In order to demonstrate the validity of the above assertion, I will address the two most compelling justifications for the application of a lesser standard than strict scrutiny. One justification, that the right of association and the right to vote are somehow less than "fundamental" in the context of ballot access law, has been explicitly rejected by the Court in the course of its ballot access jurisprudence. ${ }^{263}$ The other possible justification is that a heightened level of scrutiny would inevitably lead to undesirable results. ${ }^{264}$ While the Court has rejected this rationale in other areas of law, it evidently failed to fully appreciate the implications of its prior decisions on ballot access jurisprudence.

The Court's hesitancy to apply strict scrutiny to all infringements of fundamental rights is based on the realization that governmental regulations may infringe fundamental rights indirectly or in merely a de minimis fashion. Therefore, strict scrutiny may be excessively harsh as applied to such regulations. ${ }^{265}$ Alternatively, non-funda-

live. Other rights, even the most basic, are illusory if the right to vote is undermined." Wesberry v. Sanders, 376 U.S. 1, 17 (1964). But see Gardner supra note 3 (manuscript at 3, on file with the University of Pennsylvania Law Review) (citing Reynolds v. Sims, 377 U.S. 533, 554 (1964) and San Antonio Indep. Sch. Dist. v. Rodriguez, 411 U.S. 1, 35 n.78 (1973)) for a discussion of the Court's contradictory declarations regarding constitutional protection of the right to vote.

${ }^{262}$ See, e.g., Harper v. Virginia Bd. of Elections, 383 U.S. 663, 670 (1966) (stating that the Court has "long been mindful that where fundamental rights and liberties are asserted under the Equal Protection Clause, classifications which might invade or restrain them must be closely scrutinized and carefully confined"); Reynolds, 377 U.S. at 561-62 (stating that because "the right of suffrage is a fundamental matter . . . any alleged infringement ... must be carefully and meticulously scrutinized"); see also TRIBE, supra note 2, at 1454 ("Legislative and administrative classifications are to be strictly scrutinized and thus held unconstitutional absent a compelling governmental justification if they distribute benefits or burdens in a manner inconsistent with fundamental rights.").

263 See supra notes $65-68$ and accompanying text.

${ }^{264}$ See supra note 258 (noting the fear of anomalous results voiced by Justice Marshall inherent in a system of tiered scrutiny).

${ }^{265}$ For example, in Burdick v. Takushi, 504 U.S. 428, 433 (1992), the Court stated that "[i]t is beyond cavil that "voting is of the most fundamental significance under our constitutional structure' [but i]t does not follow ... . that the right to vote in any manner and the right to associate for political purposes through the ballot are absolute." Id. at 433 (quoting Illinois Bd. of Elections v. Socialist Workers Party, 440 U.S. 173, 184 (1979)). The Court then reasoned that, because "[e]lection laws will invariably impose some burden upon individual voters. . . . to subject every voting regulation to strict scrutiny ... would tie the hands of States seeking to assure that 
mental rights may be greatly burdened by state regulations, thus implying that the rational basis test may be insufficient. Nevertheless, the Court repeatedly has declared that a proper application of the tiered scrutiny regime does not necessarily lead to inapposite results as long as the determination of the standard is not conclusory. For example, in Adarand Constructors, Inc. v. Pena, ${ }^{266}$ the Court rejected the use of an intermediate standard of review for congressionally mandated "benign" racial classifications in favor of strict scrutiny. ${ }^{267}$ Justice O'Connor, writing for the Court, declared that "all racial classifications ... must be analyzed by a reviewing court under strict scrutiny" and that consistent standards must be applied in all instances of race-based laws. ${ }^{268}$ Therefore, Adarand specifically stands for the proposition that the Court must maintain a consistent standard of review for laws that infringe fundamental rights, regardless of the degree of infringement on individual rights or the extent of the state objectives furthered. Accordingly, "wish [ing] to dispel the notion that strict scrutiny is 'strict in theory, but fatal in fact," ${ }^{269}$ the Court declared:

The principle of consistency simply means that whenever the government treats any person unequally because of his or her race, that person has suffered an injury that falls squarely within the language and spirit of the Constitution's guarantee of equal protection. It says nothing about the ultimate validity of any particular law; that determination is the job of the court applying strict scrutiny. The principle of consistency explains the circumstances in which the inquiry requiring strict scrutiny occurs. The application of strict scrutiny, in turn, determines whether a compelling governmental interest justifies the infliction of that injury. ${ }^{270}$

elections are operated equitably and efficiently." $I d$. Thus, the Court in Burdick apparently assumed that any application of strict scrutiny would necessarily result in a finding that the state election scheme was unconstitutional. Nonetheless, as will be argued below, application of strict scrutiny is not inherently inconsistent with a finding that the rights to associate and to vote are overcome by compelling state interests.

266115 S. Ct. 2097 (1995).

${ }^{267}$ See id. at 2112 (stating that only a strict scrutiny standard can assure that "important legislative goals are pursued by using a racial classification and that the means chosen closely fit these goals").

${ }^{263} \mathrm{Id}$. at 2113.

${ }^{269} \mathrm{Id}$. at 2117 (quoting Fullilove v. Klutznick, 448 U.S. 448, 519 (1980) (Marshall, J., concurring)).

$270 \mathrm{Id}$. at 2114. 
It is simply not necessary that the Court employ a balancing test in order to "weigh [] all [of the appropriate] factors [and] decide whether the challenged [ballot access restriction] is unconstitutional."271 Rather, the application of strict scrutiny will enable a Court to make a proper determination of the constitutionality of ballot access restrictions. The Court simply cannot bury its head in the sand and ignore the totality of its equal protection jurisprudence. Because ballot access restrictions implicate "fundamental" rights, the application of strict scrutiny is required.

\section{B. Rights Asserted}

Having established in Section A that a proper equal protection analysis compels the employment of heightened scrutiny to challenges of state ballot access regulations, this Section will briefly illustrate the respective rights of the state and the individual that may be implicated by such state regulations.

\section{Individual Interests}

State ballot schemes that restrict access to minority and independent candidates implicate the rights of those candidates. Nevertheless, because the Court has not recognized candidacy as a fundamental right, assertions of burdened candidacy alone will not be sufficient to invoke strict scrutiny. ${ }^{272}$ However, as the Supreme Court stated in Bullock v. Carter, "the rights of voters and the rights of candidates do not lend themselves to neat separation; laws that affect candidates always have at least some theoretical, correlative effect on voters." 273

271 Anderson v. Celebrezze, 460 U.S. 780, 789 (1983).

${ }^{272}$ See Bullock v. Carter, 405 U.S. 134, 142-43 (1972) ("The initial and direct impact of [ballot access restrictions] is felt by aspirants for office, rather than voters, and the Court has not heretofore attached such fundamental status to candidacy as to invoke a rigorous standard of review."); see also Clements v. Fashing, 547 U.S. 957, 963 (1982) (plurality opinion) (finding that "the existence of barriers to a candidate's access to the ballot does not of itself compel close scrutiny"). Professor Tribe observed that "although groups of voters have a right to associate and advance a candidate to represent their interests, these associational rights do not seem to require that any particular individual serve as that candidate." TRIBE supra note 2, at 1098 n.5. In addition, Professor Tribe noted that it would be peculiar for the Court to find fundamental an "activity [such as candidacy, that is] bound to be unthinkable for a vast majority of [society]." Id.

${ }^{273}$ Bullock, 405 U.S. at 143. But the Court also found that "not every limitation or incidental burden on the exercise of voting rights is subject to a stringent standard 
As discussed above, the Court announced in Anderson v. Celebrezze that state election codes "inevitably affect[] . . . the individual's right to vote and his right to associate with others for political ends." ${ }^{274}$ Consequently, the Court has recognized that the rights of association and voting are necessarily implicated by ballot access restrictions. As illustrated in Part III, the Court has consistently recognized the fundamental character of these rights. ${ }^{275}$

Additionally, the Court has recognized the "significant role that third parties have played in the political development of the $\mathrm{Na}$ tion." 276 Further, because the Court has found that "an election campaign is a means of disseminating ideas as well as attaining political office," access restrictions may be viewed as infringing political expression. ${ }^{277}$

Even if ballot access restrictions do not infringe the fundamental rights of association and voting, the Court could arguably employ strict scrutiny in its analysis of state election laws dealing with third parties and independent candidates because such regulations burden a protected class of citizens. Accordingly, while inquiring into "whether the challenged restriction unfairly or unnecessarily burden [ed] the "availability of political opportunity,"”278 the Court

of review." Id. But see supra Part V.A (arguing that the Court should employ strict scrutiny to analyze all burdens on the exercise of the fundamental rights of voting and association).

${ }^{274}$ Anderson, 460 U.S. at 788. For a separate discussion of the freedom of association, see Thomas I. Emerson, Freedom of Association and Freedom of Expression, 74 YALE L.J. 1, 2 (1964) (observing that NAACP v. Alabama ex rel. Patterson, 357 U.S. 449 (1958) "elevated [the] freedom of association to an independent right, possessing an equal status with the other rights specifically enumerated in the First Amendment").

${ }^{275}$ See supra notes 258-61 and accompanying text (listing cases in which the Court acknowledged the fundamental nature of the rights to vote and associate for political ends).

${ }^{276}$ Illinois Bd. of Elections v. Socialist Workers Party, 440 U.S. 173, 185-86 (1979) ("Abolitionists, Progressives, and Populists have undeniably had influence, if not always electoral success.").

27 Id. at 186; see also ALEXANDER M. BICKEL, REFORM AND CONTINUITY 79-80 (1971) (stating that minor parties are indispensable for disseminating new ideas and that their existence is constitutionally protected); WILFRED E. BINKLEY, AMERICAN POLITICAL PARTIES 181-82 (3d ed. 1958) (noting that the Abolitionists and other third parties emerged when the major parties failed to placate their own dissident members); HOWARD R. PENNIMAN, SAIT'S AMERICAN POLITICAL PARTIES AND ELECTIONS 238-39 (5th ed. 1952) (" $[T]$ he true function of minor parties is to bring forward new policies, [and $t$ ] hrough them, sectional interests that cannot be reconciled with the existing combination of interest in the major parties may find expression ....").

${ }^{278}$ Anderson, 460 U.S. at 793 (quoting Clements v. Fashing, 457 U.S. 957, 964 (1982) (quoting Lubin v. Parish, 415 U.S. 709, 716 (1974) (quotation marks omitted))). 
in Anderson alluded to the seminal footnote number four in United States v. Carolene Products Co. and its discussion of the impact of state regulations on discrete and insular minorities. ${ }^{279}$ While the Anderson Court-after finding that burdens on minority political parties or independent candidates "by [their] very nature," impinge on First Amendment rights-used a balancing test to invalidate the state election scheme, the Court could simply treat laws directed at the politically disaffected as presumptively subject to a strict scrutiny equal protection analysis. ${ }^{280}$

\section{State Interests}

Strict scrutiny requires that "classifications, imposed by [a] federal, state, or local governmental actor . . . are constitutional only if they are narrowly tailored measures that further compelling governmental interests." ${ }^{281}$ Thus, in order for a state ballot access

279 See supra note 137 and accompanying text. The Court in Carolene Products stated that "prejudice against discrete and insular minorities may be a special condition, which tends seriously to curtail the operation of those political processes ordinarily to be relied upon to protect minorities, and which may call for a correspondingly more searching judicial inquiry." United States v. Carolene Products Co., 304 U.S. 144, 153 n.4 (1938). See also Lyng v. Castillo, 477 U.S. 635, 638 (1986) ("As a historical matter ... [strict scrutiny is given to those groups that exhibit] obvious, immutable, or distinguishing characteristics that define them as a discrete group; and they are ... a minority or politically powerless.").

In addition, Professor Tribe observed that special judicial protection is given to those groups which, "because of widespread, insistent prejudice against them," occupy the position of "perennial losers in the political struggle." TRIBE, supra note 2, at 1454.

${ }^{280}$ Anderson, 460 U.S. at 793-94. In effect, the Court implied that because minority parties and independent candidacies are established as alternatives to the "mainstream" views espoused by the two major parties, their supporters necessarily are not represented by the major parties. Thus, any state regulations that treat such groups in a disparate manner are not afforded the traditional presumption of reasonableness attributed to the legislative process as an enactment of the popular will. But since the Court in Anderson employed a balancing test to invalidate the Ohio statute, it had no occasion to consider whether the regulation would indeed receive strict scrutiny due to its impact on the politically disaffected.

281 Adarand Constructors, Inc. v. Pena, 115 S. Ct. 2097, 2113 (1995) (finding that strict scrutiny must be applied even to "benign" racial classifications imposed by the federal government); see also Harper v. Virginia Bd. of Elections, 383 U.S. 663, 670 (1966) (stating that the Court has "long been mindful that where fundamental rights and liberties are asserted under the Equal Protection Clause, classifications which might invade or restrain them must be closely scrutinized and carefully confined"); Reynolds v. Sims, 377 U.S. 533, 561-62 (1964) (stating that "the right of suffrage is a fundamental matter" and that "any alleged infringement of the right of citizens to vote must be carefully and meticulously scrutinized"); TRIBE, supra note 2, at 1454 (stating that "[l]egislative and administrative classifications are to be strictly 
regime that infringes the fundamental rights of association and voting to be found constitutional, the reviewing court must determine first that the state objectives furthered are indeed "compelling," and second that the actual regulation was less restrictive of individuals' constitutional rights than other available alternatives. Although these determinations must be made in the context of a justiciable controversy and in light of the relevant circumstances, it is possible to discuss state interests that may potentially rise to a compelling level. ${ }^{282}$ Accordingly, this subsection will briefly describe certain state interests that may be sufficient to support a state regulation that infringes upon fundamental rights. ${ }^{283}$

As an initial matter, the Court has clearly recognized that "there must be a substantial regulation of elections if they are to be fair and honest and if some sort of order, rather than chaos, is to accompany the democratic process." ${ }^{284}$ Accordingly, the Court has permitted many state regulations that serve to improve the effectiveness of the electoral system. However, the Court has recently underscored the procedural nature of state electoral schemes: "[T] he Framers understood the Elections Clause as a grant of authority to issue procedural regulations, and not as a source of power to dictate electoral out-

scrutinized and thus held unconstitutional absent a compelling governmental justification if they distribute benefits or burdens in a manner inconsistent with fundamental rights").

${ }^{282}$ See, e.g., Storer v. Brown, 415 U.S. 724, 730 (1974) (noting that decisions concerning the validity of ballot access restrictions are "very much a 'matter of degree,' very much a matter of 'considering the facts and circumstances behind the law, the interests which the State claims to be protecting, and the interests of those who are disadvantaged by the classification'") (quoting Dunn v. Blumstein, 405 U.S. 330,348 (1972) and Williams v. Rhodes, 393 U.S. 23, 30 (1968) respectively).

${ }^{283}$ For a more significant treatment of the states' rights furthered by state ballot access restrictions, see Smith, supra note 14, at 178-93 (concluding that state interests in assuring majority winners, maintaining political stability, avoiding voter confusion, discouraging frivolous candidates, and avoiding clogged voting machinery are not meaningfully advanced by ballot access restrictions); see also Judith L. Elder, Access To the Ballot by Political Candidates, 83 DICK. L. REV. 387, 390-401 (1978) (describing state interests in promoting the two-party system, assuring a majority winner, restricting the ballot to serious candidates, preventing voter confusion and apathy, and furthering administrative feasibility); James S. Jardine, Ballot Access Rights: The Constitutional Status of the Right to Run for Office, 1974 UTAH L. REv. 290, 303-07 (identifying state interests in maintaining integrity of the ballot, preventing voter confusion, ensuring competent candidacies, and providing for administrative convenience); Note, supra note 3 , at 1136-39 (discussing the importance of the state interests in preserving the two-party system and channeling factionalism into established parties).

${ }^{284}$ Storer, 415 U.S. at 730. 
comes, to favor or disfavor a class of candidates, or to evade important constitutional restraints." 285

In essence, the Court has permitted state electoral regulations that prevent elections from degenerating into "only the cacophony of an atomized body politic, not the orchestrated voice of an electorate." ${ }^{286}$ The following discussion will briefly summarize the major state interests.

\section{a. Political Stability}

The Court has consistently recognized a number of states' compelling interests under the rubric of maintaining the stability of the political system. ${ }^{287}$ This interest is based on a fundamental belief that "splintered parties and unrestrained factionalism may do significant damage to the fabric of government." ${ }^{288}$ Therefore, restraining intraparty and interparty competition may validly further the goal of political stability.

A state's interest in limiting intraparty competition is effectuated by limiting "sore-loser" candidacies. ${ }^{289}$ Consequently, the Court in Storer found that the state election code's preclusion of "sore-loser" candidacies was constitutional, concluding that " $[t]$ he general election ballot is reserved for major struggles; it is not a forum for continuing intraparty feuds." 290

In addition, states have a valid interest in protecting against destructive forms of interparty feuding. Thus, states may enact legislation to eliminate interparty raiding which is generally defined as "the organized switching of blocs of voters from one party to

${ }^{285}$ U.S. Term Limits, Inc. v. Thornton, 115 S. Ct. 1842, 1869 (1995).

286 TRIBE, supra note 2, at 1097.

287 See Storer, 415 U.S. at 736 (recognizing "the State's interest in the stability of its political system" and "consider[ing] that interest as not only permissible, but compelling").

${ }^{288} I d$.

${ }^{289}$ See, e.g., id. at 735; Anderson v. Celebrezze, 460 U.S. 780, 783 (1983); Patriot Party v. Ailegheny County Dep't of Elections, 95 F.3d 253, 264 (2d Cir. 1996). A soreloser candidacy is one in which an individual loses in a party primary and then seeks to run as an independent or as a minor party candidate. See, e.g., Anderson, 460 U.S. at 783 (citing OHIO REV. CODE ANN. § 3513.04 (Supp. 1982)).

290 Storer, 415 U.S. at 735; see also Burdick v. Takushi, 504 U.S. 428, 439 (1992) (finding that a state's prohibition of write-in voting is a legitimate means of averting sore-loser candidacies); Tashjian v. Republican Party, 479 U.S. 208, 219 (1986) (recognizing the state's interest in seeking to curtail the raiding of one party's primary by voters sympathetic to the other party); Munro v. Socialist Workers Party, 479 U.S. 189,196 (1986) (holding that states may condition ballot access on a showing of a modicum of voter support). 
another in order to manipulate the outcome of the other party's primary election."291

Perhaps the state interest that will become the most controversial in future challenges to access restrictions is the preservation of the two party system. The Court in Williams $v$. Rhodes ${ }^{292}$ rejected Ohio's election scheme as a mechanism designed to entrench the two existing parties, finding that the ballot access laws granted the major parties a permanent monopoly in the electoral system. ${ }^{293}$ However, the Court stated that "the Ohio system does not merely favor a 'twoparty system'; it favors two particular parties ... and in effect tends to give them a complete monopoly." 294 Thus, it is reasonable to assume that the Court in Williams accepted that a state might have a legitimate interest in maintaining the viability of the two party system, but that Ohio's regulation was simply overdrawn. ${ }^{295}$

291 Anderson, 460 U.S. at 788-89 n.9; see also Burdick, 504 U.S. at 439.

292393 U.S. 23 (1968).

${ }^{293}$ See id. at 32; discussion supra Part III.A (observing that the Ohio election code required any new political party desiring to be placed on the ballot to file petitions signed by qualified electors totaling $15 \%$ of the number of ballots cast in the preceding election, and also imposed excessive party organizational requirements).

${ }^{294}$ Id. (emphasis added).

${ }^{295}$ But see Note, supra note 3, at 1138 (suggesting that the Court in Williams "identified but dismissed" the state's interest in furthering a two-party system). However, the author asserted that " $[\mathrm{i}] \mathrm{t}$ seems undeniable that the political stability that a two-party system fosters, by encouraging 'a politics of coalition and accommodation rather than ... ideological and charismatic fragmentation,' is a compelling state interest" and concluded that the state's interest in the preservation of the two-party system is "[b]y far [one of the] most important state interests." Id. (quoting BICKEL, supra note 277 , at 21-22)).

Scholars have viewed political parties as cohesive influences in an otherwise decentralized structure of government. See, e.g., EDWARD C. BANFIELD, POLITICAL INFLUENCE 237 (1961) (observing that "[b]y far the most important mechanism through which . . . formal decentralization is . . . overcome by informal centralization ... is the political party"); EDWARD C. BANFIELD \& JAMES A. WILSON, CiTY POLiTICS 101 ("In order for anything to be done under pubic auspices, the elaborate decentralization of authority ... must somehow be overcome .... $)$. The Framers essentially created a formally decentralized system that would require the ad hoc centralization of authority and power in order to effectively govern society. Political parties are thus a significant factor in enabling the American government to function. But see Michael Fitts \& Robert Inman, Controlling Congress: Presidential Influence in Domestic Fiscal Policy, 80 GEO. L.J. 1737, 1741 (1992) (observing that in addition to its "institutional decentralization ... Congress today lacks strong political parties as an alternative, informal, centralizing force"). Additionally, the desire to retain power on a long-term basis forces political parties to act more responsibly than individuals might otherwise. Finally, political parties have a more comprehensive view of society and posterity, and thus act in a more holistic and forward-looking manner than individual politicians. See Michael A. Fitts, Can Ignorance Be Bliss? Imperfect Information As a Positive Influence in Political Institutions, 88 MICH. L. REV. 917, 920-23 (1990) 


\section{b. Political Legitimacy}

The Court has also recognized the "substantial state interest . . . in attempting to ensure that the election winner will represent a

[hereinafter Fitts, Ignorance] (arguing that in some circumstances, relying on strong, centralized political institutions to disseminate information to the public can have potential policy effects); Michael A. Fitts, Look Before You Leap: Some Cautionary Notes on Civic Republicanism, 97 YALE L.J. 1651, 1656-57 (1988) ("[P]olitical parties serve to centralize authority, creating large scale institutions that attract diffuse majority support and overcome some of the collective action problems in popular political organization as well as government administration."); Michael A. Fitts, The Vices of Virtue: A Political Party Perspective on Civic Virtue Reforms of the Legislative Process, $136 \mathrm{U}$. PA. L. REv. 1567, 1603 (1988) (arguing that "centralized political systems are thought to enhance majority rule, reduce collective action problems, and improve the operation of the decisional processes"); id. at 1628-29 (providing a historical discussion of the decentralized power structure in Congress and the decline of political parties).

For a more complete discussion of the value of the two-party system, see BICKEL, supra note 277, at 22 (stating that "the dominance of [the] two major parties enables us to achieve a politics of coalition and accommodation rather than of ideological and charismatic fragmentation, governments that are moderate, and a regime that is stable"). Bickel notes that a two-party system "tend[s] to ensure that there are few irreconcilable losers, and that the winners can govern, even though-or perhaps because-there are equally few total victories." Id.; see also Zywicki, supra note 63, at 139 (advocating a reduction in the interference of federal courts in the review of state ballot access laws).

In addition, other scholars have noted that as voters have become increasingly less committed to the two major parties, the states' interest in encouraging the two party system has become "quite substantial." Terry Smith, Election Law: Election Laws and First Amendment Freedoms-Confusion and Clarification by the Supreme Court, 1988 ANN. SURV. AM. L. 597, 611-12.

Finally, although the Constitution does not address the phenomenon of political parties in any sense, political organizations were certainly no mystery to the men who attended the Constitutional Convention in 1787. In perhaps the most famous of the Federalist Papers, Federalist Number 10, James Madison discussed the issue of "factions" with the New York populace, stating that " $[t]$ he latent causes of faction are thus sown in the nature of man." THE FEDERALIST No. 10, at 79 (James Madison) (Clinton Rossiter ed., 1961). Madison noted that "the causes of faction cannot be removed and the relief is only to be sought in the means of controlling its effects." Id. Madison also observed that, as factions were unavoidable in a representative democracy and were also necessary to provide informal cohesion, the regulation of "factions" would be a principle task of government action. For further discussion of Madison's views of factions, see Stephen G. Calabresi, Political Parties as Mediating Institutions, 61 U. CHI. L. REV. 1479, 1485 (1994) (observing that Madison "hated and feared factions").

For a brief discussion and rationale of why the United States political system evolved into a two-party system, see BoTT, supra note 3, at 88-93. 
majority of the community." ${ }^{296}$ In his dissent in Williams, Justice Stewart observed that:

Ohio's provisions tend to guard against the possibility that smallparty candidates will draw enough support to prevent either of the major contenders from obtaining an absolute majority of votesand against the consequent possibility that election may be secured by candidates who gain a plurality but who are, vis-à-vis their principal opponents, preferred by less than half of those voting. . . . [I] $t$ is inconceivable to me that the Constitution imposes on the States a political philosophy under which they must be satisfied to award election on the basis of a plurality rather than a majority vote. ${ }^{297}$

\section{c. Avoiding Voter Confusion}

Finally, the Court has recognized the states' interest in ensuring that a voter's decision will be a rational and informed one. Consequently, the Court has acknowledged that "'a State has an interest, if not a duty, to protect the integrity of its political processes from frivolous or fraudulent candidacies." 298 States have legitimate

${ }^{296}$ Storer v. Brown, 415 U.S. 724, 729 (citing Williams v. Rhodes, 393 U.S. 23, 32 (1968)); see also Illinois State Bd. of Elections v. Socialist Workers Party, 440 U.S. 173, 185 (1979) (discussing the Court's previous recognition of the states' interest in limiting the number of candidates on the ballot); Bullock v. Carter, 405 U.S. 134, 145 (1972) (discussing the legitimate state interest in making sure that a winning candidate is the choice of a majority or strong plurality of voters).

297 Williams, 393 U.S. at 53-54 (Stewart, J., dissenting); see also Zywicki, supra note 63 , at 122-23. In contrast, the federal system allows candidates who secure less than a majority of the popular vote to win the presidency. See BOTT, supra note 3, at 87-88 ("The Twelfth Amendment ... provide[s] that votes be cast separately for the president and vice president.... [T] he person receiving the highest number of electoral votes cast for the presidency is president, and the person receiving the highest number of votes cast for the vice presidency is vice president."). Three times in American history "a person who received the majority of the popular vote did not receive the majority of electoral votes and therefore did not become president." Id. at 88 (Andrew Jackson (1824), Samuel Tilden (1876), Grover Cleveland (1888)). Conversely, it is possible for a person who receives less than a majority of the popular vote to become president. This happened in 1992, when Bill Clinton received more votes than either then-President George Bush or Ross Perot, but did not receive a majority. See Charles Krauthammer, Modest Election, Personal Defeat, WASH. POST, Nov. 7, 1992, at A21 (noting that President Clinton's 1992 win, with only 43\% of the popular vote, was the lowest percentage captured by a successful presidential candidate since 1860). In 1996, President Clinton received more votes than either Robert Dole or Ross Perot but again did not receive a majority.

298 Storer, 415 U.S. at 733 (quoting Bullock, 405 U.S. at 145). 
interests in "prevent[ing] the clogging of ... election machinery, avoid[ing] voter confusion ... [and] avoiding overcrowded ballots." 299 These interests have been found on numerous occasions to justify state ballot access regulations that require a "preliminary showing of a significant modicum of support before printing the name of a political organization's candidate on the ballot. ${ }^{n 00}$

\section{Indication of Court's Present View}

As discussed in Part III, the Supreme Court's most recent discussion on ballot access restrictions was U.S. Term Limits, Inc. v. Thom$t_{0 n}{ }^{301}$ In determining that an amendment to the Arkansas Constitution that precluded persons who had served a certain number of terms in the U.S. Congress from having their names placed on the ballot was unconstitutional, the Court rested its decision on a finding that the U.S. Constitution prohibited states from imposing additional congressional qualifications. ${ }^{302}$ Nevertheless, because the amendment had been articulated as a ballot access restriction, the Court found occasion to address its "Elections Clause cases." ${ }^{03}$ The Court held that "the Elections Clause [was intended] to grant States [the] authority to create procedural regulations, not to provide States with license to exclude classes of candidates from federal office." 304

To emphasize the procedural focus of the Elections Clause, the Court quoted James Madison, stating that the Clause dealt with " $[w]$ hether the electors should vote by ballot or vivâ voce, should assemble at this place or that place; should be divided into districts or all meet at one place, sh [oul]d all vote for all the representatives; or all in a district vote for a number allotted to the district." "305 The Court in U.S. Term Limits concluded that:

The Elections Clause gives States authority "to enact the numerous requirements as to procedure and safeguards which experience shows are necessary in order to enforce the fundamental right involved." However, "[t]he power to regulate the time, place, and

${ }^{299}$ Id. at 732-33 (quoting Bullock, 405 U.S. at 145).

${ }^{300}$ Jenness v. Fortson, 403 U.S. 431, 442 (1971).

${ }^{301}$ See discussion supra Part III.C; see also U.S. Term Limits, Inc. v. Thornton, 115 S. Ct. 1842 (1995).

${ }^{302}$ See U.S. Term Limits, Inc., 115 S. Ct. at 1845, 1871.

${ }^{303} I d$. at 1870 .

${ }^{304} I d$. at 1869.

${ }^{305}$ Id. (citation omitted). 
manner of elections does not justify, without more, the abridgement of fundamental rights." 306

In essence, the Court's opinion states that ballot access restrictions should be purely functional in character. Nevertheless, because the Court's statements in U.S. Term Limits concerning access restrictions were as cryptic as its previous jurisprudence, this issue remains far from resolved. The Court's reference to "without more" may indicate that compelling state interests, such as those discussed above, will allow for more burdensome election schemes. Alternatively, the Court may have intended that only some state interests, in addition to and apart from traditional interests in regulating the ballot, will suffice to uphold the constitutionality of burdensome ballot access restrictions. This view is substantiated by the Court's conclusion that:

The provisions at issue in Storer and our other Elections Clause cases were thus constitutional because they regulated election procedures and did not even arguably impose any substantive qualification rendering a class of potential candidates ineligible for ballot position. They served the state interest in protecting the integrity and regularity of the election process. ${ }^{307}$

Thus, it is possible that in the future the Court will recognize only procedural rationales as sufficient justifications for restrictive ballot access schemes.

However, in declaring that the "Elections Clause gives States authority to '. . . enforce the fundamental right involved," the Court may have suggested that procedural regulation of the electoral process was a fundamental right of the state and hence a "compelling" state objective. ${ }^{308}$ Thus, U.S. Term Limits may imply that restrictive state ballot access regimes could survive strict scrutiny if they further procedural objectives.

${ }^{906}$ Id. at 1869-70 (quoting Smiley v. Holm, 285 U.S. 355, 366 (1932) and Tashjian v. Republican Party, 479 U.S. 208, 217 (1986) respectively) (alteration in original, emphasis added) (citation omitted).

${ }^{307}$ Id. at 1870 .

${ }^{308}$ Id. at 1869 (quoting Smiley, 285 U.S. at 366) (omission in original). 


\section{CONCLUSION}

The United States appears to be entering a period marked by significant upheaval in the political landscape. ${ }^{309}$ Persistent skepticism of the "existing order" has taken the form of challenges to incumbents and party-supported candidates by "outside" candidates, ${ }^{310}$ third party candidates, and increasing support for a viable third party. As these political forces attempt to effectuate change in American society via the governmental structure, they confront complex state election machinery that hinders, and often precludes, their ballot access. Increasingly, these political upstarts have challenged the restrictive ballot access laws in the courts. As the popular desire for alternative political choices escalates, so too will the number of legal challenges.

This Comment illustrated the lack of clarity and the inconsistency of the Supreme Court's historical jurisprudence in the area of state ballot access restrictions, which has left lower courts confused as to the proper method of analysis. This situation should be remedied quickly. In fact, because of the increasing frequency of legal challenges accompanying minority and third party challenges to Republicans and Democrats at the ballot, ${ }^{311}$ the Supreme Court will likely decide a ballot access restriction case shortly.

This Comment argues that as a remedy, ballot access restrictions must be examined through the tiered scrutiny analysis utilized by the Court in traditional equal protection and substantive due process challenges. Access restrictions necessarily implicate the freedom of political association and the right to vote, both of which the Court has accepted without question, to be fundamental in character. As strict scrutiny was created to protect fundamental rights, it is logically inconsistent and intuitively unreasonable for the Court to deny this heightened scrutiny to two of our "most precious freedoms." Therefore, the Court should employ a strict scrutiny analysis that recognizes the fundamental nature of the individual rights infringed and enables states to regulate effectively the elections process. Such an analysis must recognize states' interests in maintaining political stability, promoting political legitimacy, and avoiding voter confu-

${ }^{309}$ See supra notes 5-6 and accompanying text.

${ }^{310}$ For example, Patrick Buchanan challenged then-President George Bush in the Republican primary process for the party's nomination in the 1992 presidential election.

311 See supra Part IV.

${ }^{312}$ Williams v. Rhodes, 393 U.S. 23, 30 (1968). 
sion. Significantly, the Court must acknowledge that states do have a legitimate and compelling interest in maintaining a two-party system, but also must prevent states from entrenching the two existing parties in their positions of power. The Court should strike a balance between the competing values of pure democracy and governability-creating a ballot access regime that allows for change in the substance of political ideology, but protects the formal and informal governmental structures that enable our government to function. Having entered the "political thicket" in 1968, the Court should now establish order in the area of ballot access restrictions by constructing a jurisprudential framework that will provide consistency, fairness and administrability. Our "most precious freedoms" may depend on it. ${ }^{313}$ 
